\author{
MONIKA KACZAŁA, KRZYSZTOF ŁYSKAWA \\ https://doi.org/10.33995/wu2020.4.3
}

\title{
Wpływ ubezpieczeń dotowanych upraw na wynik finansowy wybranych rodzajów produkcji roślinnej
}

Wzrost liczby i natężenia zjawisk o charakterze katastroficznym oraz konieczność ograniczenia pomocy ad hoc państwa doprowadziły do wprowadzenia dotowanych ubezpieczeń upraw w Polsce. Zakres zmieniajacych się notorycznie regulacji prawnych oraz ograniczony popyt powoduja jednak, że należy postawić pytanie o efektywność ubezpieczeń dotowanych dla najważniejszych podmiotów - gospodarstw rolnych. Celem opracowania jest określenie wpływu korzystania z ubezpieczeń dotowanych na wynik finansowy uzyskiwany z produkcji roślinnej w zakresie wybranych upraw (rzepaku, pszenicy ozimej, kukurydzy na ziarno] w odniesieniu do skutków złego przezimowania oraz suszy. Cel zrealizowano, przeprowadzajac symulacje wyników finansowych w wybranych uprawach oraz dodatkowo obliczajqc dwa wskaźniki, tj. stopień pokrycia przez odszkodowanie kosztów bezpośrednich i zdolność odtworzenia majqtku. Stwierdzono, że efektywność ochrony ubezpieczeniowej zależy w przypadku ubezpieczenia od skutków złego przezimowania na równi od parametrów ekonomicznych funkcjonowania gospodarstwa, jak i stosowanych regulacji w zakresie technicznych uwarunkowań umów ubezpieczenia. Natomiast w przypadku ubezpieczenia od skutków suszy - od stawki za ubezpieczenie oraz poziomu franszyzy redukcyjnej.

Słowa kluczowe: ubezpieczenia upraw, skutki złego przezimowania, susza, wynik finansowy, produkcja roślinna.

\section{Wstęp}

Dotowanie ubezpieczeń w rolnictwie jest praktyką stosowaną przez coraz więcej państw. Działania takie moga mieć różne uzasadnienie, zarówno w obszarze ekonomicznym, jak i prawnym. Zgodnie z treścią Uzasadnienia do pierwszej wersji polskiej ustawy o ubezpieczeniach upraw i zwierząt 
gospodarskich z 2005 roku ${ }^{1}$ drożone regulacje miały umożliwić wydatkowanie środków budżetowych na dopłaty do ubezpieczeń, co z kolei miało doprowadzić do ich upowszechnienia. Jednocześnie przygotowywane regulacje miały pozwolić państwu polskiemu na zbudowanie mechanizmu, który gwarantowałby pokrywanie strat w gospodarstwach rolnych w przypadku wystapienia nieprzewidzianych zdarzeń losowych i odciążyć budżet w zakresie pomocy ad hoc. Wejście Polski w struktury Unii Europejskiej zmniejszyło znacznie liczbę możliwych do zastosowania instrumentów pomocy sektorowi rolnemu w przypadku wystapienia zjawisk katastroficznych. Ubezpieczenia nie zostały jednak wyłączone z tego katalogu. Jednocześnie regulacje zawarte w Rozporzadzeniu 1885/2005 wskazywały, że realizacja pełnej pomocy ad-hoc (udzielanej po zdarzeniu katastroficznym) rolnikom wymaga posiadania ubezpieczenia co najmniej połowy areału². W konsekwencji celem wdrożenia ustawy było zbudowanie narzędzia, które zwiększy zaufanie producentów rolnych do nowego mechanizmu pomocy w sytuacji zajścia zdarzeń katastroficznych. Jednak szczegółowa analiza technicznych zapisów pierwotnych regulacji, a następnie wprowadzanych nowelizacji ${ }^{3}$ wskazuje, że zakres świadczonej ochrony może znacznie odbiegać od oczekiwanego w ubezpieczeniach majatkowych pełnego pokrycia straty przez wypłacane odszkodowanie.

Celem niniejszego opracowania jest określenie wpływu korzystania z ochrony ubezpieczeniowej w ubezpieczeniach dotowanych na wynik finansowy uzyskiwany z produkcji roślinnej w zakresie wybranych upraw. Jest to więc analiza prowadzona z punktu widzenia producenta rolnego i stanowić może wstęp do szerszych rozważań dotyczących opłacalności i efektywności korzystania z ochrony ubezpieczeniowej. Cel zrealizowano, przeprowadzając symulacje wyników finansowych w wybranych uprawach oraz dodatkowo obliczając dwa wskaźniki, tj. stopień pokrycia przez odszkodowanie kosztów bezpośrednich oraz zdolność odtworzenia majatku. Analizie poddano dwa najtrudniejsze do ubezpieczenia zjawiska, tj. skutki złego przezimowania oraz suszę w odniesieniu do szkód w trzech uprawach: rzepaku, pszenicy ozimej oraz kukurydzy na ziarno (ta ostatnia przy szkodach spowodowanych złym przezimowaniem była uprawą zastępcza]). Uprawy te wybrano z tego powodu, że zboża, kukurydza i rzepak stanowią 62\% wszystkich ubezpieczonych upraw ${ }^{4}$. Analizę przeprowadzono na dzień 30 września 2020 roku, a więc w okresie poprzedzającym jesienny sezon ubezpieczenia upraw.

1. Ustawa z dnia 7 lipca 2005 r. o dopłatach do ubezpieczeń upraw rolnych i zwierząt gospodarskich (Dz. U. 2005, nr 150, poz. 1249).

2. W efekcie wprowadzenia w 2007 r. obowiązku ubezpieczenia $50 \%$ areału ustawa zmieniła swój główny charakter. $Z$ instrumentu umożliwiającego dotowanie składek w ubezpieczaniu upraw stała się odpowiedzią na wymagania określone przez Unię Europejską. Zgodnie z rozporządzeniem Komisji (WE) nr 1857/2006 z dnia 15 grudnia 2006 r. w sprawie stosowania art. 87 i 88 Traktatu w odniesieniu do pomocy państwa dla małych i średnich przedsiębiorstw prowadzących działalność związaną z wytwarzaniem produktów rolnych oraz zmieniającym rozporządzenie (WE) nr 70/2001 (Dz.Urz. L 358 z 16.12.2006), dodatkowa pomoc ze strony państwa dla producentów rolnych w przypadku zaistnienia zjawisk katastroficznych jest możliwa tylko w sytuacji, gdy dany producent ubezpieczył co najmniej połowę swojego areału od najczęściej występujących zjawisk katastroficznych na danym obszarze.

3. Od dnia uchwalenia pierwszej wersji ustawy o ubezpieczeniach upraw i zwierząt gospodarskich była ona nowelizowana 14 razy. Od 2019 r. nie wprowadzono żadnych zmian, a od 2020 r. trwają intensywne dyskusje nad kolejną nowelizacja. Ustawa z dnia ? lipca 2005 r. o ubezpieczeniach upraw rolnych i zwierząt gospodarskich (tekst jedn. Dz. U 2019, poz. 477); dalej: ustawa o ubezpieczeniach upraw.

4. NIK, Wspieranie środkami publicznymi systemu ubezpieczeń rolniczych, https://www.nik.gov.pl/ kontrole/P/19/047/, s. 20 [dostęp: 10.09.2020]. 
Wpływ ubezpieczeń dotowanych upraw na wynik finansowy wybranych rodzajów...

Niniejsze opracowanie zostało zrealizowane w ramach projektu UBROL, który uzyskał dofinansowanie Narodowego Centrum Badań i Rozwoju (NCBR) z programu GOSPOSTRATEG w ramach Umowy nr Gospostrateg1/390422/25/NCBR/2019.

\section{Zakres stosowania ustawy o ubezpieczeniach dotowanych upraw}

Uchwalona w lipcu 2005 roku ustawa o ubezpieczeniach upraw objęła swoim zakresem przedmiotowym podstawowe uprawy rolne (zboża, kukurydzę, rzepak, rzepik, ziemniaki, buraki cukrowe) oraz najważniejsze gatunki zwierząt gospodarskich (bydło, konie, owce, kozy i świnie). W pierwotnej wersji ustawy, po korekcie zakresu chronionych zdarzeń ${ }^{5}$, ubezpieczenia dotowane dotyczyły w odniesieniu do upraw następujących zdarzeń losowych: huraganu, powodzi, deszczu nawalnego, gradu, piorunu, obsunięcia się ziemi, lawiny, suszy, ujemnych skutków przezimowania lub przymrozków wiosennych. Jednocześnie zakres ten mógł być oferowany tylko łącznie, w pakiecie. Jednak nowelizacja z 2007 roku wprowadziła możliwość rozdzielenia ryzyk, gdyż istniała obawa, że zakłady ubezpieczeń nie będą miały możliwości technicznych (np. w zakresie zasad likwidacji szkód z powodu suszy] i finansowych prowadzenia ubezpieczeń w pełnym zakresie. Od samego początku w ustawie wprowadzono pojęcie maksymalnej stawki, jaką moga pobierać zakłady ubezpieczeń, aby producenci rolni zachowali prawo do dotacji ${ }^{6}$.

Kluczowe znaczenie dla sytuacji na rynku miała zmiana w ustawie z lipca 2008 roku, która odnosiła się do zakresu ubezpieczeń przymusowych? Zapisany w nowelizacji z 2007 roku obo-

5. W związku z tym, że omawiane ubezpieczenie miało stać się nową formą pomocy dla sektora rolnego, to zgodnie z rozporządzeniem Rady (WE) nr 659/1999 z dnia 22 marca 1999 r. ustanawiajacym szczegółowe zasady stosowania art. 93 Traktatu WE (Dz.Urz.UE.L 1999 Nr 83, str. 1) ustawa podlegała notyfikacji Komisji Europejskiej. Po uchwaleniu przez Sejm Rzeczypospolitej Polskiej ustawa została przesłana do Komisji Europejskiej. Pismem z dnia 19 grudnia 2005 r. (znak D-40646) Komisja Europejska zwróciła się o dokonanie zmian w przedłożonym przez Polskę systemie dopłat do ubezpieczeń upraw rolnych i zwierząt gospodarskich, polegających na wyłączeniu z tego systemu ryzyka ognia i eksplozji. Wyjaśnienia Komisji wskazywały, że ryzyko ognia i eksplozji powinno wchodzić w zakres ubezpieczenia handlowego, zawieranego przez samego rolnika - bez ingerencji państwa.

6. Już w pierwotnej wersji ustawy pojawił się zapis, iż składka w przypadku dotowanych ubezpieczeń upraw nie może przekroczyć 3,5\% sumy ubezpieczenia. W nowelizacji z $?$ marca 2007 r. wcześniej podany próg pozostawiono tylko w odniesieniu do wysokości dopłaty dla zbóż, kukurydzy, rzepaku jarego, rzepiku, ziemniaków lub buraków cukrowych, w odniesieniu zaś do innych upraw próg wynosił $5 \%$ maksymalnej składki, od której naliczana jest dopłata 50\%. Jednocześnie ustalono, że dopłata do składki przysługuje, jeżeli stawka nie przekracza $6 \%$. Brak dopłaty w przypadku przekroczenia $6 \%$ zniesiono w lipcu 2015 r. dla warzyw gruntowych oraz drzew i krzewów owocowych. W 2017 r. wprowadzono nowe stawki maksymalne - 9\% sumy ubezpieczenia, a w przypadku upraw prowadzonych na słabych glebach $12 \%$ (gleby klasy V) i 15\% (gleby klasy VI). Przekroczenie tego limitu początkowo powodowało utratę prawa do dopłaty. Po czterech miesiącach jednak (czyli przed rozpoczęciem sezonu wiosennego) regulację tę zmieniono. Przy przekroczeniu stawek (liczonych zarówno dla całego pakietu dziesięciu możliwych zdarzeń, jak i dla sumy stawek dla zdarzeń wybranych) dopłaty były pomniejszane proporcjonalnie do procentu ich podwyższenia, bez uwzględniania stawek taryfowych dla suszy i ujemnych skutków przezimowania (zasada ta została złagodzona dla upraw drzew i krzewów owocowych oraz truskawek, gdzie przekroczenie uprawniało do dopłaty według stawek maksymalnych). Takie rozwiązanie skutkuje tym, że nawet bardzo wysokie stawki za ubezpieczenie od skutków suszy nie powodują zmniejszenia stopnia dopłaty.

7. Ubezpieczenia przymusowe definiowane jako: „ubezpieczenia, co do których przymus ubezpieczenia został co prawda wyrażony przez ustawodawcę, lecz nie w sposób wyraźny i stanowczy", za: M. Orlicki, Ubezpie- 
wiązek zawarcia umowy ubezpieczenia od pięciu zdarzeń (skutki złego przezimowania, przymrozki wiosenne, grad, susza i powódź) był przedmiotem wielu dyskusji ${ }^{8}$. Nowelizacja z 2008 roku wprowadziła konieczność zawarcia umowy ubezpieczenia dla 50\% posiadanych areałów pól uprawnych od co najmniej jednego z pięciu ryzyk. W związku z tym to producentowi rolnemu pozostawiono decyzję o zakresie niezbędnego dla siebie programu ubezpieczeniowego, czyli które pola ubezpiecza i w jakim zakresie ${ }^{9}$.

\section{Zasady funkcjonowania ubezpieczeń dotowanych w odniesieniu do skutków złego przezimowania i suszy}

\subsection{Skutki złego przezimowania}

Szczegółowa analiza szkód wypłaconych przez zakłady ubezpieczeń od 2008 roku wskazuje, iż w każdym z minionych lat pojawiało się zjawisko atmosferyczne, które skutkowało znacznymi wypłatami. Wartościowo największe odszkodowania wypłacane przez ubezpieczycieli dotyczyły jednak strat poniesionych przez rolników w wyniku skutków złego przezimowania upraw ozimych. W 2011 roku wypłacono z tego tytułu ponad 160 mln zł odszkodowań, w 2012 roku - ponad 500 mln zł, zaś w 2016 roku - ponad 600 mln zł. W analizowanych latach uprawą, która najbardziej ucierpiała, był rzepak. Należy jednak podkreślić, iż w tych okresach zarejestrowano również szkody w zbożach, co dla wielu rolników było sytuacją zaskakującą i niespotykaną wcześniej w ich doświadczeniach. W konsekwencji opisanych zjawisk szkodowych szczegółowej analizie wpływu posiadania ubezpieczenia na wynik finansowy poddano rzepak ozimy (przy zastosowaniu jako uprawy alternatywnej kukurydzy na ziarno] oraz pszenicę ozimą.

Ekonomiczna konstrukcja ubezpieczenia skutków złego przezimowania w uprawach ozimych polega na tym, że zakład ubezpieczeń wypłaca określony ryczałt w sytuacji, gdy po zejściu śniegów i ruszeniu wiosennej wegetacji okazuje się, że liczba żywych roślin na polu lub jego części jest na tyle mała, że nie gwarantuje odpowiedniego plonu i w konsekwencji osiągnięcia zysku, czy nawet pokrycia poniesionych kosztów. Pomimo braku szczegółowych regulacji w ustawie o ubezpieczeniach upraw w zakresie symptomów szkód związanych z przezimowaniem, każde z towarzystw w treści swoich warunków (Concordia, Vereinigte Hagelversicherung) lub normach likwidacyjnych (PZU, Pocztowy) szczegółowo zdefiniowało zasięg pojęć wymarznięcia, wymoknięcia, wyprzenia, wysmalenia czy wysadzenia roślin. W zakresie rozumienia tych zjawisk nie ma różnic pomiędzy towarzystwami ubezpieczeniowymi i rolnikami. Należy jednak podkreślić, iż zmiany agrotechniczne i jakość materiału siewnego doprowadziły do zmiany wartości granicznych ilości roślin, które oznaczają szkodę. Tuż po wdrożeniu omawianej ustawy standardem w odniesieniu do uprawy rzepaku ozimego było, iż szkoda pojawia się, gdy gęstość zasiewu spada poniżej 25 szt. żywych roślin na 1 $\mathrm{m}^{2}$. W warunkach stosowanych w 2020 roku jest to 15 szt. Zmiany technologiczne w zakresie upraw powodują, że przy mniejszej ilości roślin rolnicy są w stanie uzyskać plonowanie (przy odpowiednim

czenia obowiqzkowe, Wolter Kluwer, Warszawa 2011, s.171-175.

8. Zob. np. Materiały z konferencji „Kierunki zmian ubezpieczeń produkcji rolnej w Polsce”, zorganizowanej przez Polskq Izbę Ubezpieczeń w Warszawie w dniu 4.02.2008 r.

9. M. Janowicz-Lomott, K. Łyskawa, Funkcjonowanie dotowanych ubezpieczeń upraw w Polsce, „Wiadomości Ubezpieczeniowe" 2016, nr 2, s. 69-92. 
przebiegu pogody na wiosnę], które zapewni możliwość uzyskania odpowiedniego przychodu z jednego hektara. Szczegółowe regulacje w zakresie definicji szkody, minimalnych kryteriów dla roślin przed zakończeniem jesiennej wegetacji oraz wysokości odszkodowania prezentuje poniższa tablica.

Tablica 1. Definicja szkody z tytułu skutków złego przezimowania w różnych typach roślin w 2020 r.

\begin{tabular}{|c|c|c|c|c|c|}
\hline & PZU S.A. & VH Polska & $\begin{array}{c}\text { Concordia Polska } \\
\text { S. A. }\end{array}$ & $\begin{array}{l}\text { InterRisk TU } \\
\text { S.A. VIG }\end{array}$ & POCZTOWY TUW \\
\hline & \multicolumn{5}{|c|}{ UJEMNE SKUTKI PRZEZIMOWANIA } \\
\hline $\begin{array}{l}\text { Wysokość } \\
\text { odszkodowania }\end{array}$ & $\begin{array}{l}\text { Szkoda } \\
\text { do 15 kwietnia } \\
10 \% .17 \% \text { lub } \\
\text { 25\% sumy } \\
\text { ubezpieczenia } \\
\text { dla powierzchni } \\
\text { uszkodzonej } \\
\text { uprawy, } \\
\text { w zależności } \\
\text { od wariantu, } \\
\text { w którym została } \\
\text { zawarta umowa } \\
\text { ubezpieczenia } \\
\text { po zaistnieniu } \\
\text { szkody } \\
\text { na powierzchni } \\
\text { powyżej 10\% } \\
\text { (lub 8\%) pola } \\
\text { Szkoda } \\
\text { po 15 kwietnia } \\
40 \% \text { sumy } \\
\text { ubezpieczenia } \\
\text { dla powierzchni } \\
\text { uszkodzonej } \\
\text { uprawy } \\
\text { po zaistnieniu } \\
\text { szkody } \\
\text { na powierzchni } \\
\text { powyżej 10\% } \\
\text { (lub 8\%) pola. }\end{array}$ & \begin{tabular}{|l}
$15 \%$ lub \\
$25 \%$ sumy \\
ubezpieczenia \\
dla powierzchni \\
uszkodzonej \\
uprawy, \\
w zależności \\
od wariantu, \\
w którym została \\
zawarta umowa \\
ubezpieczenia \\
po zaistnieniu \\
szkody \\
na powierzchni \\
powyżej 10\% \\
(lub 8\%) pola
\end{tabular} & \begin{tabular}{|l}
$15 \%$ lub \\
$25 \%$ sumy \\
ubezpieczenia \\
dla powierzchni \\
uszkodzonej \\
uprawy, \\
w zależności \\
od wariantu, \\
w którym została \\
zawarta umowa \\
ubezpieczenia \\
po zaistnieniu \\
szkody \\
na powierzchni \\
powyżej 10\% \\
(lub 8\%) pola
\end{tabular} & \begin{tabular}{|l}
$15 \%$ lub \\
$20 \%$ sumy \\
ubezpieczenia \\
dla powierzchni \\
uszkodzonej \\
uprawy, \\
w zależności \\
od wariantu, \\
w którym została \\
zawarta umowa \\
ubezpieczenia \\
po zaistnieniu \\
szkody \\
na powierzchni \\
powyżej 10\% \\
(lub 8\%) pola
\end{tabular} & \begin{tabular}{|l} 
Szkoda \\
do 15 kwietnia \\
17\% sumy \\
ubezpieczenia \\
dla powierzchni \\
uszkodzonej \\
uprawy \\
po zaistnieniu \\
szkody \\
na powierzchni \\
powyżej 10\% \\
(lub 8\%) \\
Szkoda \\
po 15 kwietnia \\
$40 \%$ sumy \\
ubezpieczenia \\
dla powierzchni \\
uszkodzonej \\
uprawy \\
po zaistnieniu \\
szkody \\
na powierzchni \\
powyżej 10\% \\
(lub 8\%)
\end{tabular} \\
\hline $\begin{array}{l}\text { Minimalne } \\
\text { kryteria dla } \\
\text { roślin przed } \\
\text { zakończeniem } \\
\text { jesiennej } \\
\text { wegetacji }\end{array}$ & $\begin{array}{l}\text { jęczmień ozimy: } \\
200 \text { szt./m² } \\
\text { pszenica ozima: } \\
250 \text { szt./m² } \\
\text { pszenżyto } \\
\text { ozime: } 200 \text { szt./ } \\
\text { m² }^{2} \\
\text { żyto ozime: } \\
200 \text { szt./m² } \\
\text { rzepak ozimy: } \\
25 \text { szt./m² }\end{array}$ & $\begin{array}{l}\text { jęczmień ozimy: } 3 \\
\text { liście, } 150 \text { szt./m² } \\
\text { pszenica ozima: } 2 \\
\text { liście, } 250 \text { szt./m² } \\
\text { pszenżyto ozime: } \\
2 \text { liście, } \\
250 \text { szt./m² } \\
\text { żyto ozime: } \\
3 \text { liście, } \\
120 \text { szt./m² } \\
\text { rzepak ozimy: } \\
8 \text { liści, } 30 \text { szt./m² }\end{array}$ & $\begin{array}{l}\text { jęczmień ozimy: } 3 \\
\text { liście, } 150 \text { szt./m² } \\
\text { pszenica ozima: } 2 \\
\text { liście, } 250 \text { szt./m² } \\
\text { pszenżyto ozime: } \\
2 \text { liście, } \\
200 \text { szt./m² } \\
\text { żyto ozime: } \\
3 \text { liście, } \\
120 \text { szt./m² } \\
\text { rzepak ozimy: } \\
8 \text { liści, } 30 \text { szt./m² }\end{array}$ & $\begin{array}{l}\text { jęczmień ozimy: } \\
3 \text { liście, } \\
180 \text { szt./m² } \\
\text { żyto ozime: } \\
3 \text { liście, } \\
140 \text { szt./m² } \\
\text { pszenżyto ozime: } \\
3 \text { liście, } \\
200 \text { szt./m² } \\
\text { pszenica ozima: } \\
3 \text { liście, } \\
250 \text { szt./m² } \\
\text { rzepak ozimy: } \\
6 \text { liści, } 30 \text { szt./m² }\end{array}$ & $\begin{array}{l}\text { jęczmień ozimy: } \\
200 \text { szt./m² } \\
\text { pszenica ozima: } \\
250 \text { szt./m² } \\
\text { pszenżyto ozime: } \\
200 \text { szt./m² } \\
\text { żyto ozime: } \\
200 \text { szt./m² } \\
\text { rzepak ozimy: } \\
30 \text { szt./m² } \\
(20 \text { szt./m² } \\
\text { dla wysiewu } \\
\text { punktowego) }\end{array}$ \\
\hline
\end{tabular}




\begin{tabular}{|c|c|c|c|c|c|}
\hline $\begin{array}{l}\text { Wielkość } \\
\text { obsady } \\
\text { poniżej której } \\
\text { uznawana jest } \\
\text { szkoda }\end{array}$ & $\begin{array}{l}\text { jęczmień ozimy: } \\
90 \text { szt./m² } \\
\text { pszenica ozima: } \\
130 \text { szt./m² } \\
\text { pszenżyto ozime: } \\
90 \text { szt./m² } \\
\text { żyto ozime: } \\
100 \text { szt./m² } \\
\text { rzepak ozimy: } \\
15 \text { szt./m² }\end{array}$ & $\begin{array}{l}\text { jęczmień ozimy: } \\
100 \text { szt./m² } \\
\text { pszenica ozima: } \\
130 \text { szt./m² } \\
\text { pszenżyto ozime: } \\
100 \text { szt./m² } \\
\text { żyto ozime: } \\
80 \text { szt./m² } \\
\text { rzepak ozimy: } \\
15 \text { szt./m² }\end{array}$ & $\begin{array}{l}\text { jęczmień ozimy: } \\
100 \text { szt./m² } \\
\text { pszenica ozima: } \\
120 \text { szt./m² } \\
\text { pszenżyto ozime: } \\
100 \text { szt./m² } \\
\text { żyto ozime: } \\
80 \text { szt./m² } \\
\text { rzepak ozimy: } \\
15 \text { szt./m² }\end{array}$ & $\begin{array}{l}\text { jęczmień ozimy: } \\
120 \text { szt./m² } \\
\text { pszenica ozima: } \\
140 \text { szt./m² } \\
\text { pszenżyto ozime: } \\
120 \text { szt./m² } \\
\text { żyto ozime: } 100 \\
\text { szt./m² } \\
\text { rzepak ozimy: } 20 \\
\text { szt./m² }\end{array}$ & $\begin{array}{l}\text { jęczmień ozimy: } \\
90 \text { szt./m² } \\
\text { pszenica ozima: } \\
130 \text { szt./m² } \\
\text { pszenżyto ozime: } \\
90 \text { szt./m² } \\
\text { żyto ozime: } \\
100 \text { szt./m² } \\
\text { rzepak ozimy: } \\
15 \text { szt./m² } \\
\text { (12 szt./m² } \\
\text { dla wysiewu } \\
\text { punktowego) }\end{array}$ \\
\hline
\end{tabular}

* W przypadku PZU S. A. wypłacane odszkodowanie jest dodatkowo obniżane o 10\% udziału własnego. Źródło: opracowanie własne na podstawie ogólnych warunków zakładów ubezpieczeń.

Po zaistnieniu szkody z tytułu złego przezimowania nie ma już obowiązku przesiania pola i wprowadzenia uprawy zastępczej (uprawy jarej). W efekcie producent rolny sam zarządza konsekwencjami ekonomicznymi i agrotechnicznymi w zakresie pola dotkniętego szkoda. Przy podejmowaniu decyzji odnośnie do przesiania uszkodzonych roślin ozimych (np. rzepaku, pszenicy ozimej) należy brać pod uwagę: rachunek ekonomiczny na uprawie zastępczej w stosunku do skutków finansowych pozostawienia uprawy ozimej bez zaorania, planowanie płodozmianów w wieloleciu, zastosowanie wcześniej odpowiednich herbicydów. Obowiązujące od 2008 roku przepisy pozwalają zatem na świadome zarządzanie ryzykiem przez producentów rolnych w zakresie kontynuacji danej uprawy (przy obniżonych oczekiwanych plonach) lub wprowadzenie uprawy zastępczej.

\subsection{Skutki suszy}

Badania dotyczące postrzegania ryzyka w gospodarstwach rolnych jednoznacznie wskazuja, że susza rolnicza jest oceniana jako najgroźniejsze zdarzenie, którego częstotliwość i skutki dla gospodarstw rolnych będą wzrastać ${ }^{10}$. Największe deficyty wody - obliczane na podstawie średnich wieloletnich sum opadów i ewapotranspiracji potencjalnej w sezonie wegetacyjnym - występuja w obszarach Niżu Polskiego z epicentrum w Wielkopolsce ${ }^{11}$. Wpływ deficytu wody na plonowanie jest zależny od potrzeb wodnych roślin, ich fazy rozwoju oraz rozkładu i rodzaju opadów. Potrzeby wodne roślin różnią się między soba. W odniesieniu do analizowanych poniżej upraw w obszarze

10. M. Kaczała, Systemowe ryzyko suszy rolniczej a ubezpieczenia. Zadania dla państwa, Wydawnictwo Uniwersytetu Ekonomicznego w Poznaniu, Poznań 2019, s. 83-85 oraz Identyfikacja podstaw, przemian i problemów ubezpieczeń rolnych, [red.] M. Soliwoda, Instytut Ekonomiki Rolnictwa i Gospodarki Żywnościowej - Państwowy Instytut Badawczy, Warszawa 2020, s. 584-591.

11. P. Koza, A. Łopatka, J. Jadczyszyn, R. Wawer, A. Doroszewski, G. Siebielec, Ekspertyza „Wyznaczenie obszarów w różnym stopniu zagrożonych wystapieniem suszy w Polsce na potrzeby wdrażania operacji „Modernizacja gospodarstw rolnych" Programu Rozwoju Obszarów Wiejskich na lata 2014-2020", Puławy 2019, https:// www.gov.pl/web/rolnictwo/publikacje, s. 5 [dostęp: 10.10.2020]. 
nizin środkowej Polski najniższe potrzeby ma pszenica (270-300 mm), następnie rzepak (350$400 \mathrm{~mm}$ ), natomiast najwyższe kukurydza na ziarno $(450-480 \mathrm{~mm})^{12}$.

Umowy ubezpieczenia upraw obejmujące skutki suszy stanowiły w całym okresie funkcjonowania ustawy o ubezpieczeniach dotowanych upraw zaledwie niewielki ułamek wszystkich umów ubezpieczenia upraw. W latach 2017, 2018 oraz I półroczu 2019 roku ryzyko suszy pokryto w ramach 1980 umów, co stanowiło zaledwie 0,4\% wszystkich umów dotowanych ubezpieczeń upraw, a odszkodowania wypłacone z tego tytułu - 0,1\% łącznej sumy wypłaconych odszkodowań ${ }^{13}$. Oferta zakładów ubezpieczeń była bardzo ograniczona - ubezpieczenia te można było nabyć w praktyce w 2018 oraz 2019 roku tylko w pakietach, choć na rynku znaleźć można było początkowo także oferty ubezpieczenia tylko od skutków suszy (których jednak ostatecznie nie zawierano). W 2020 roku ubezpieczenie dotowane od skutków suszy było dostępne tylko w Pocztowe TUW oraz PZU14. Jednak małe limity sum ubezpieczenia na poszczególne województwa lub opóźnione przeprowadzanie oględzin upraw sprawiły, iż z ubezpieczenia od suszy skorzystało ok. 1300 rolników. Straty w uprawach rolniczych spowodowanych suszą sạ jednak bardzo wysokie. Z uwagi na bardzo niską penetrację ubezpieczeniową w zakresie ubezpieczenia upraw od suszy wielkość wypłaconych odszkodowań z tego tytułu nie odzwierciedla rzeczywistych rozmiarów szkód spowodowanych niedoborem wody. Szacując rozmiar szkód, można posiłkować się wyliczeniami dokonywanymi przez komisje powołane przez wojewodę. Komisje takie szacuja wielkość szkód na poczet ubiegania się przez rolników o pomoc na odtwarzanie potencjału produkcji rolnej. W okresie 2015-2019 susza była w latach 2015, 2016, 2018 oraz 2019 głównym niekorzystnym zjawiskiem pogodowym szacowanym przez komisje, a straty nią spowodowane wyniosły w 2015 roku 3,06 mld zł (tylko susza), w 2018 roku - 8,59 mld zł (susza i powódź, przy czym głównym zjawiskiem była susza), w 2019 roku - 10, 8 mld zł (susza, huragan, grad, deszcz nawalny, przymrozki wiosenne lub powódź, przy czym głównymi zjawiskami były susza i przymrozki wiosenne] ${ }^{15}$.

Zasady dotyczące dotowanych ubezpieczeń upraw zmieniały się od 2006 roku wielokrotnie ${ }^{16}$. Od listopada 2018 roku obowiązuje 25\% franszyza integralna, franszyza redukcyjna w wysokości 20\%, 25\%, 30\% (do wyboru) oraz 14-dniowa karencja ubezpieczeniowa. Skutki suszy można ubezpieczyć w pakiecie z innymi zagrożeniami lub samodzielnie. Definicja zdarzenia opiera się na pomiarze klimatycznego bilansu wodnego (KBW). Suszę oznaczają szkody spowodowane wystapieniem, w dowolnym sześciodekadowym okresie od dnia 21 marca do dnia 30 września, spadku KBW poniżej wartości określonej dla poszczególnych gatunków roślin uprawnych i gleb. Spadek ten powoduje przeciętnie 20\% spadek plonów w stosunku do wartości średnich wieloletnich. Ponadto w ramach dotowanych ubezpieczeń od skutków suszy oferowane jest wsparcie państwa (dotacja celowa) dla zakładów ubezpieczeń w wysokości 60\% różnicy pomiędzy łączną kwotą odszkodowań wypłaconych w danym roku kalendarzowym z tytułu szkód spowodowanych przez suszę a kwotą stanowiącą 90\%

12. L. Łabędzki, Potrzeby wodne roślin uprawnych i potrzeby nawodnień w zlewni rzeki Zgłowiqczki, WIRZ 2007, nr 4, s. 5.

13. NIK, op. cit., s. 33, 35.

14. Oferta Concordii Polska SA była skierowana tylko do wybranych rolników, którzy ubezpieczyli swoje zboża ozime jesienią w zakresie szerokiego pakietu.

15. MRiRW, Ubezpieczenia z uwzględnieniem stabilizacji dochodów jako instrumenty zarzqdzania ryzykiem w rolnictwie, Warszawa, 29 września $2020 \mathrm{r}$.

16. Szczegółowe omówienie zmian zob. np. M. Kaczała, op. cit., s. 141-153. 
sumy składek uiszczonych w danym roku kalendarzowym z tytułu zawarcia umów ubezpieczenia upraw (liczonych łącznie z dotacjami). Dotacja ta, stanowiąca rodzaj reasekuracji końcowej, miała zachęcić zakłady ubezpieczeń do zaangażowania się w ubezpieczenia od skutków suszy.

Funkcjonowanie dotowanych ubezpieczeń upraw od skutków suszy w Polsce rodzi wiele kontrowersji, które - jak dotąd - nie zostały rozstrzygnięte satysfakcjonująco dla wszystkich stron. Świadczy o tym znikoma liczba umów ubezpieczenia. Do najważniejszych problemów należą m.in. funkcjonowanie franszyzy integralnej (spory w zakresie faktycznego spadku plonowania względem wskazywanej wartości krytycznej ${ }^{17}$ ], definicja zdarzenia suszy i oparcie go wyłącznie o KBW, którego wiarygodność jest podważana ze względu na zbyt małą liczbę stacji pomiarowych i ich nieadekwatne zagęszczenie, wysokie stawki za ubezpieczenie od skutków suszy, złożoność i koszty likwidacji szkody, nasilający się charakter zjawiska oraz jego występowanie na znacznym obszarze, co powoduje konieczność zabezpieczenia wysokich środków w zakładach ubezpieczeń, a także brak danych statystycznych dotyczących zjawiska.

\section{Kalkulacja wyniku finansowego dla szkód w zakresie skutków złego przezimowania oraz suszy}

\subsection{Założenia przyjęte w obliczeniach}

Wyjściowe kalkulacje wyniku finansowego przyjęto za Wielkopolską Izbą Rolniczą na wrzesień 2020 roku, sporządzone dla przeciętnego 15-hektarowego gospodarstwa położonego w Wielkopolsce. Kalkulacje nadwyżki bezpośredniej wykonano na podstawie aktualnych cen płodów i środków do produkcji rolnej. Obrazują one rzeczywiste rozwiązania stosowane przez przeciętnych rolników w Wielkopolsce. Uwzględniają koszty produkcji rolnej bezpośrednie oraz pośrednie (materiał siewny, nawożenie, ochronę roślin, usługi, pracę ciagnika, sznurek oraz koszty ogólnogospodarcze, w tym amortyzację, składki na ubezpieczenie społeczne, ubezpieczenie obowiązkowe budynków rolniczych, energię elektryczną itp.).

Do kalkulacji przyjęto dane odnośnie do plonowania i kosztów ubezpieczenia przedstawione w tab. 2. W kalkulacjach szczegółowych rozróżniono dwie sytuacje:

1) kalkulacja wyniku upraw ozimych (rzepak, pszenica ozima) przy zastosowaniu uprawy zastępczej w postaci kukurydzy na ziarno;

2) kalkulacja wyniku analizowanych upraw przy uwzględnieniu kosztów ubezpieczenia od suszy.

Przyjęte sumy ubezpieczenia nie przekraczaja sum maksymalnych wyznaczonych Rozporządzeniem Ministra Rolnictwa i Rozwoju Wsi z dnia 27 listopada 2019 roku w sprawie maksymalnych sum ubezpieczenia dla poszczególnych upraw rolnych i zwierząt gospodarskich na rok 2020 (Dz. U. 2019, poz. 2333).

17. Określone w ramach Systemu Monitoringu Suszy wskaźniki wartości krytycznych KBW były dotychczas zmieniane czterokrotnie ( w formie Rozporządzenia Ministra Rolnictwa i Rozwoju Wsi) i w każdym przypadku wprowadzano korektę, która wskazywała, że susza powinna być ogłaszana wcześniej lub jej intensywność jest większa wglądem dotychczas obowiązujących przepisów. 
Tablica 2. Stawki ubezpieczeniowe i wysokość składki dla rolnika przed dotacją przyjęte do kalkulacji kosztów ubezpieczenia - według wybranych rodzajów upraw i zakresów ubezpieczenia

\begin{tabular}{|c|c|c|c|c|c|}
\hline Rodzaj uprawy & $\begin{array}{l}\text { Plon } \\
\text { (dt) }\end{array}$ & $\begin{array}{l}\text { Cena } \\
\text { [dt] }\end{array}$ & Zakres ubezpieczenia & $\begin{array}{c}\text { Stawka } \\
\text { szacowana }\end{array}$ & $\begin{array}{l}\text { Składka } \\
\text { na } 1 \text { ha }\end{array}$ \\
\hline \multirow{2}{*}{ rzepak ozimy } & \multirow{2}{*}{35} & \multirow{2}{*}{161,55} & $\begin{array}{l}\text { Skutki złego przezimowania, przymrozek } \\
\text { wiosenny, grad }\end{array}$ & $5,20 \%$ & 294,02 \\
\hline & & & Susza* & $4,8 \%$ & 271,4 \\
\hline \multirow{2}{*}{ pszenica ozima } & \multirow[t]{2}{*}{60} & \multirow[t]{2}{*}{68,06} & $\begin{array}{l}\text { Skutki złego przezimowania, przymrozek } \\
\text { wiosenny, grad }\end{array}$ & $3,00 \%$ & 122,51 \\
\hline & & & Susza* & $6 \%$ & 245,02 \\
\hline \multirow{2}{*}{ kukurydza ziarno } & \multirow{2}{*}{80} & \multirow{2}{*}{74} & Grad, przymrozek wiosenny & $2,90 \%$ & 171,68 \\
\hline & & & Susza* & $21,9 \%$ & 1296,5 \\
\hline
\end{tabular}

* Przy kalkulacji składek za ubezpieczenie za 2019 r. zastosowano stawkę za ubezpieczenie tylko od skutków suszy (wg taryf rynkowych otrzymanych od zakładów ubezpieczeń, pomimo że takie ubezpieczenie w praktyce nie było oferowane - dostępne było tylko w pakietach). Przyjęte stawki dotyczą klasy gleby IVa-IVb, która jest klasą dominująca w Wielkopolsce.

Źródło: opracowanie własne na podstawie danych zakładu ubezpieczeń.

Wartości stawek i składek z tab. 2 zostały wykorzystane do kalkulacji odszkodowań oraz wyników produkcji w poszczególnych typach upraw. Wyniki te zaprezentowano w tab. 3-?.

\subsection{Dodatkowe miary wykorzystane w analizie}

Z punktu widzenia rachunkowości zarządczej gospodarstwo jest traktowane jak normalna firma, gdzie nastapiła już zapłata za pracę (rolnikowi), a przychody musza pokryć nie tylko wydatki, ale również koszty amortyzacji. Składka za ubezpieczenie upraw stanowi koszt produkcji i pomniejsza tym samym wynik finansowy uzyskiwany na 1 ha uprawy. To, jak ostatecznie wpłynie na jego wysokość, zależy od wielkości szkody i stopnia jej pokrycia przez odszkodowanie. Wynik finansowy przekłada się na zdolność gospodarstwa do dokonywania inwestycji. Poziom tego potencjalnego wpływu może zostać mierzony za pomocą wskaźnika „Zdolności odtworzenia majątku gospodarstwa" (ZOM). Przyjmuje on następująca postać ${ }^{18}$ :

$$
Z O M=100 \%+\left(\frac{W F}{A} \times 100 \%\right)
$$

gdzie

ZOM - zdolność odtworzenia majątku gospodarstwa

WF - wynik finansowy uzyskany na uprawie z 1 ha

$A$ - amortyzacja środków trwałych przypadająca na 1 ha uprawy

Wskaźnik ten informuje zatem, czy osiagnnięty wynik finansowy umożliwia reprodukcję zawężona, prostą czy rozszerzona majątku trwałego wykorzystywanego w produkcji ${ }^{19}$. W przypadku,

18. K. Pabiszczak, G. Wysocki, Kalkulacje rolnicze, „Siewca Wielkopolski” 2001, nr 6, s. 14-15.

19. Zob. szerzej A. Grzelak, Ocena procesów reprodukcji majqtku gospodarstw rolnych prowadzqcych rachunkowość rolnq (FADN), „Zagadnienia Ekonomiki Rolnej” 2014, nr 3, s. 4 ?. 
gdy wynik finansowy jest ujemny, to wartość wskaźnika jest <100, co oznacza, że gospodarstwo nie odtwarza majatku (konsumowany jest majątek, często poprzednich pokoleń). W dłuższym okresie, pomimo braku widocznych zmian w strukturze gospodarstwa (areał, liczba zwierząt czy obiektów), prowadzi to do ograniczenia możliwości rozwoju z własnego potencjału (reprodukcja zawężona). Gdy stan taki trwa długo, zachodzi konieczność uzyskania wsparcia z zewnętrznych źródeł finansowania (kredytu bankowego), co może dodatkowo pogłębić negatywny rezultat kalkulacji wyniku finansowego i jeszcze bardziej zaniżyć wskaźnik ZOM (kumulacja zdarzeń w postaci gorszych wyników plonowania i konieczności dalszego opłacania zobowiązań kredytowych). W sytuacji, gdy wynik finansowy jest równy 0 , możliwa jest reprodukcja prosta - gospodarstwo odtwarza majątek zużyty do produkcji. Natomiast w przypadku, gdy wynik finansowy jest dodatni, to ZOM>100, co oznacza, że gospodarstwo dysponuje środkami, które może przeznaczyć na dodatkowe inwestycje i realizację reprodukcji rozszerzonej (powiększyć swój areał, co zmniejszy koszty amortyzacji na 1 ha lub rozwinąc się technologicznie).

W przypadku skutków suszy został także obliczony wskaźnik pokrycia przez należne odszkodowanie kosztów bezpośrednich uprawy według wzoru:

$$
W_{p k b}=\frac{0}{K B} \times 100 \%
$$

gdzie

$W_{p k b}$ - wskaźnik pokrycia kosztów bezpośrednich

0 - należne odszkodowanie na 1 ha

$K B$ - koszty bezpośrednie produkcji na 1 ha

Wskaźnik ten został obliczony tylko dla szkód spowodowanych suszą, co było bezpośrednio podyktowane chęcia weryfikacji argumentu przytoczonego przez ustawodawcę w Uzasadnieniu do ustawy z dnia 23 października 2018 roku o zmianie ustawy o ubezpieczeniach upraw rolnych i zwierząt gospodarskich. Ustawodawca, wprowadzając franszyzę redukcyjną w wysokości 20\%, 25\% lub 30\%, stwierdził, że „[... ] producent rolny będzie mógł wybrać najbardziej odpowiadający sobie wariant ubezpieczenia, zawierający również ryzyko wystapienia suszy, a tym samym uzyskania odszkodowania w przypadku poniesienia strat w produkcji w wyniku suszy i odzyskania co najmniej poniesionych kosztów na tẹ produkcję"20 (wyróżnienie autorów).

\subsection{Kalkulacja wyniku finansowego w zakresie szkód złego przezimowania}

Poniżej dokonano zestawienia symulacji warunków funkcjonowania gospodarstw rolnych przy ubezpieczeniu rzepaku ozimego / pszenicy ozimej od skutków złego przezimowania oraz uprawy zastępczej w postaci kukurydzy na ziarno (tab. 3).

20. Druk nr 2909. Rzadowy projekt ustawy o zmianie ustawy o ubezpieczeniach upraw rolnych i zwierząt gospodarskich - uzasadnienie, http://www.sejm.gov.pl/Sejm8.nsf/druk.xsp?nr=2909 [dostęp: 16.12.2020]. 
Wpływ ubezpieczeń dotowanych upraw na wynik finansowy wybranych rodzajów...

Tablica 3. Kalkulacja opłacalności uprawy rzepaku ozimego, pszenicy ozimej i kukurydzy na ziarno w zł na 1 hektar (stan na wrzesień 2020)

\begin{tabular}{|c|c|c|c|c|c|}
\hline & & & $\begin{array}{c}\text { Rzepak } \\
\text { ozimy }\end{array}$ & $\begin{array}{c}\text { Pszenica } \\
\text { ozima }\end{array}$ & \begin{tabular}{|c|} 
Kukurydza \\
na ziarno
\end{tabular} \\
\hline Nakład & llość & Cena & \multicolumn{3}{|c|}{ Wartość } \\
\hline 1. Materiał siewny $(\mathrm{dt})$ & $0,04 / 2,5 / 1,8 /$ & $\begin{array}{c}10000 / \\
190,96 / 240\end{array}$ & 400,00 & 477,40 & 432,00 \\
\hline $\begin{array}{l}\text { 2. Nawożenie (Saletra amonowa, } \\
\text { Polifoska 6-20-30, Ca/Mg co } 4 \text { lata) }\end{array}$ & & & 1311,34 & 1067,50 & 1477,57 \\
\hline 3. Ochrona roślin & & & 508,17 & 198,50 & 301,00 \\
\hline $\begin{array}{l}\text { 4. Usługi (kombajnowanie, } \\
\text { wapnowanie plus prasa, sznurek) }\end{array}$ & & & 384,76 & 589,76 & 1572,50 \\
\hline $\begin{array}{l}\text { 5. Praca ciagnika (orka, siew, } \\
\text { opryski, transport) }\end{array}$ & & & 580,19 & 765,80 & 560,87 \\
\hline 6. Podatek & & & 135,90 & 135,90 & 135,90 \\
\hline 7. Ubezpieczenie OC działalności & & & 3,90 & 3,90 & 3,90 \\
\hline Razem koszty bezpośrednie & & & 3330,36 & 3244,86 & 4489,84 \\
\hline 8. Koszty ogólnogospodarcze & & & 1025,65 & 1025,65 & 1025,65 \\
\hline w tym amortyzacja & & & 684,45 & 755,95 & 668,73 \\
\hline 9. Koszt pracy ludzkiej (godz./zł) & $30 / 35 / 28$ & 17 & 510,00 & 595,00 & 476,00 \\
\hline Suma kosztów & & & 4859,91 & 4859,41 & 5985,39 \\
\hline \multicolumn{6}{|l|}{ Wartość produkcji } \\
\hline Produkt główny (netto) (dt) & $35 / 60 / 80$ & $\begin{array}{c}161,55 / \\
68,06 / 74,00 \\
\end{array}$ & 5654,25 & 4083,60 & 5920,00 \\
\hline Ryczałtowy zwrot VAT [\%] & $?$ & & 395,80 & 285,85 & 414,40 \\
\hline $\begin{array}{l}\text { Produkt uboczny (słoma], dopłata } \\
\text { do materiału siewnego (dt) }\end{array}$ & 20 & 10,99 & & 461,24 & \\
\hline Dopłata bezpośrednia ${ }^{21}$ & & & 936,16 & 936,16 & 936,16 \\
\hline Suma przychodów & & & 6986,21 & 5766,85 & 7270,56 \\
\hline Wynik finansowy & \multicolumn{2}{|c|}{$\begin{array}{l}\text { bez szkód i kosztów } \\
\text { ubezpieczenia upraw }\end{array}$} & 2126,30 & 907,44 & 1285,17 \\
\hline Wynik finansowy & \multicolumn{2}{|c|}{$\begin{array}{c}\text { z uwzględnieniem składki za ubez- } \\
\text { pieczenia upraw bez dotacji }\end{array}$} & 1832,28 & 784,93 & 1113,49 \\
\hline Wynik finansowy & \multicolumn{2}{|c|}{$\begin{array}{|cc|}\text { z uwzględnieniem } & \text { składki } \\
\text { za ubezpieczenia upraw z dotacja }\end{array}$} & 2023,39 & 864,56 & 1225,08 \\
\hline \multicolumn{3}{|c|}{ Zdolność odtworzenia majątku gospodarstwa [w\%] } & 391,70 & 213,10 & 281,56 \\
\hline
\end{tabular}

Źródło: opracowano na podstawie: http://wir.org.pl/asp/kalkulacje-kosztow-produkcji,189,,1 [dostęp: 20.09.2020].

Dla wyliczenia kluczowego ryzyka, jakim są straty w wyniku skutków złego przezimowania, posłużono się szczegółową kalkulacją opłacalności upraw rzepaku ozimego oraz pszenicy ozimej (czyli rośliny o dużych nakładach w okresie jesiennym) oraz kukurydzy na ziarno (jako uprawy zastępczej). Przy szczegółowej kalkulacji dla poszczególnych upraw założono, iż ubezpieczane są one w pełnym zakresie - określonym w tab. 2: uprawy ozime w pełnym zakresie (skutki złego

21. Poziom dopłaty został określony jako wartość $w$ zł na 1 ha. Ale w przypadku dużych przedsiębiorstw rolnych ma miejsce zastosowanie tzw. cappingu, czyli obniżenie całości dopłaty do maksymalnej kwoty dopuszczonej przez regulacje Komisji Europejskiej. W polskiej rzeczywistości oznacza to brak dopłaty dla gruntów powyżej ok. 1030 ha. 
przezimowania, przymrozki wiosenne, grad), kukurydza na ziarno (grad oraz przymrozki wiosenne). Produkcja rzepaku ozimego przy założeniu braku szkód pozwoliłaby w 2020 roku na osiagnięcie wyniku finansowego na 1 ha na poziomie 2 126,30 zł, co jest wypadkowa wartości rynkowej nasion i bardzo dobrego plonowania. Jednak zaistnienie na przykład skutków złego przezimowania wymagałoby poniesienia nowych nakładów na założenia uprawy zastępczej - kukurydzy na ziarno. Przy cenach z jesieni 2020 roku na materiał siewny, nawozy oraz cenach na kukurydzę wyniki na 1 ha uprawy kukurydzy na ziarno wynosiłby 1 285,17 zł/ha. Jeżeli do tego dodać wartość nakładów poniesionych jesienią na założenie plantacji rzepaku ozimego (ok. 1350 zł/ha), to produkcja kukurydzy na ziarno - pomimo że sama dała pozytywny wynik - może przynieść stratę dla producenta rolnego w kontekście efektów na 1 ha uprawy (wynik końcowy z produkcji kukurydzy minus nakład jesienny na rzepak). Realizowane przez rolnika długookresowe planowanie odmian oraz udział w programach rolnośrodowiskowych wymusza wysianie określonych rodzajów upraw. Ubezpieczenie całej uprawy rzepaku ozimego od trzech zdarzeń (a szczególnie od skutków złego przezimowania) zabezpiecza częściowo wynik finansowy w przypadku ewentualnego wymarznięcia. Po wymarznięciu ubezpieczonego rzepaku zakład ubezpieczeń wypłaci ryczałt w wysokości 15\% szacowanego przychodu. To kolejna bardzo trudna do zaakceptowania zmiana w ofercie zakładów ubezpieczeń w oferowanych ubezpieczeniach dotowanych upraw, która staje się jednak trwałą tendencją ${ }^{22}$. W powyższej kalkulacji byłoby to odpowiednio 848,14 zł. To, łącznie z wynikiem osiągniętym na uprawie kukurydzy, pozwoli na uzyskanie wyniku finansowego na 1 ha na poziomie zbliżonym do dobrego roku w uprawie rzepaku, a w konsekwencji umożliwi spokojny zakup czynników do produkcji na kolejny rok. Osiagnięta łącznie wartość dodatnich przepływów w przypadku ubezpieczenia od skutków złego przezimowania to 1225,08 zł zysku na kukurydzy oraz różnica pomiędzy poniesionymi nakładami na rzepak i uzyskanym odszkodowaniem ( 1350 zł minus 848,14zł). Oznacza to, że wskaźnik ZOM jest powyżej 100\% i pozwala na odtworzenie zdolności produkcyjnych gospodarstwa (pozwala na inwestycje). Bez zawarcia umowy ubezpieczenia od skutków złego przezimowania wskaźnik ZOM byłby poniżej 100\%.

Tablica 4. Scenariusze szkodowe dla ubezpieczenia skutków złego przezimowania (wyliczenia dla 1 ha)

\begin{tabular}{|c|c|c|}
\hline & Scenariusz 1 - rzepak ozimy & Scenariusz 2 - pszenica ozima \\
\hline Szkoda z przezimowania & Tak - 15\% sumy ubezp. & Tak - $25 \%$ sumy ubezp. \\
\hline Nakłady jesienne & $1350,00 \mathrm{zł}$ & $950,00 \mathrm{zł}$ \\
\hline $\begin{array}{l}\text { Odszkodowanie } \\
\text { za wymarznięcie }\end{array}$ & $848,14 \mathrm{zł}$ & $1020,90 \mathrm{zł}$ \\
\hline $\begin{array}{l}\text { Wynik na uprawie zastępczej } \\
\text { (z ubezpieczeniem } \\
\text { kukurydzy) }\end{array}$ & $1225,08 \mathrm{zł}$ & $1225,08 \mathrm{zł}$ \\
\hline $\begin{array}{l}\text { Wynik łaczny bez } \\
\text { ubezpieczenia uprawy ozimej }\end{array}$ & $\begin{array}{c}-124,92 \mathrm{zł} \\
(1225,08 \mathrm{z} \nmid-1350,00 \mathrm{z}\})\end{array}$ & $\begin{array}{c}275,08 z ł \\
(1225,08 z ł-950,00 z ł)\end{array}$ \\
\hline $\begin{array}{l}\text { Wynik łączny } \\
\text { z ubezpieczeniem od skutków } \\
\text { złego przezimowania }\end{array}$ & $\begin{array}{c}723,22 \mathrm{zł} \\
(1225,08 \mathrm{z} \nmid-1350,00 \mathrm{zł}+848,14 \mathrm{zł})\end{array}$ & $\begin{array}{c}1295,98 \mathrm{z} \nmid \\
(1225,08 z ł-950,00 z ł+1020,90 z ł)\end{array}$ \\
\hline
\end{tabular}

Źródło: opracowanie własne.

22. Szczegółowa analiza warunków oferowanych przez poszczególne zakłady ubezpieczeń jednoznacznie wskazuje, że przejście z ryczałtu 15\% sumy ubezpieczenia na 1 ha na $25 \%$ wiąże się z bardzo dużą zmianą ceny (często stawka wzrasta nawet o 30\% za pełne ubezpieczenie pakietowe), a w niektórych towarzystwach nie ma możliwości uzyskania ochrony na wyższym poziomie ryczałtu. 
W odniesieniu do wymarznięcia uprawy pszenicy ozimej wynik finansowy przy zastosowaniu uprawy zastępczej wyniósłby 881,52 zł [1 225,08zł [efekt kukurydzy] minus 950,00 zł [nakład na jesień na pszenicę] plus 612,54 zł [15\% świadczenia za wymarzniętą uprawę na $1 \mathrm{ha}$ ]). Pozwala on na osiagnięcie wskaźnika ZOM powyżej 100\%. Dodatkowo w przypadku pszenicy ozimej zakłady ubezpieczeń są bardziej skłonne do realizacji ubezpieczenia skutków złego przezimowania z ryczałtem $25 \%$ sumy ubezpieczenia. W konsekwencji wypłacone odszkodowanie ryczałtowe mogłoby wynieść nawet 1 020,90 zł.

\subsection{Kalkulacja wyniku finansowego w zakresie skutków suszy}

Poniżej przedstawiono kalkulacje dotyczące wyniku finansowego na 1 ha uprawy w przypadku zajścia szkód suszowych różnej wielkości ( tab. 5, tab. 6, tab. ?). Posłużono się kalkulacjami wyniku finansowego zaprezentowanymi w tab. 3. Strata ubezpieczeniowa w wielkości x\% oznacza ubytek w przychodach z uprawy w wielkości x\%. W odniesieniu do upraw, gdzie występuje plon uboczny, tj. pszenicy, przyjęto, że redukcja plonu ubocznego jest taka, jak plonu głównego. Stosunek ziarna do słomy jest zależny od licznych czynników występujacych w trakcie wegetacji, a także sposobu jej zbioru ${ }^{23}$. Badania jednak wskazuja, że przy przyjętej w kalkulacjach wydajności stosunek ziarna do zbioru słomy wyjściowej jest stabilny ${ }^{24}$. Stąd w kalkulacjach założono, że redukcja plonu słomy jest wprost proporcjonalna do redukcji plonu ziarna. Ze względu na to, że oszacowanie spadku kosztów bezpośrednich w wyniku zajścia zdarzenia suszy jest zależne od wielu czynników, w tym przede wszystkim od momentu wystapienia zdarzenia, przyjęto, że redukcja plonów nie powoduje redukcji kosztów bezpośrednich. Jeśli susza zajdzie późno, pewnej redukcji mogą ulec ewentualnie koszty zbioru, ale nie nakłady na nawożenie czy ochronę roślin. W przypadku gdy susza wystapi na początku okresu wegetacji, nakłady na nawożenie czy ochronę mogą ulec redukcji, ale trudno stwierdzić, w jakim stopniu. Przy kalkulacji wyników finansowych bez ubezpieczenia od skutków suszy przyjęto, że uprawy nie są ubezpieczone od żadnego innego zdarzenia. Ponadto przyjęto, że przy stawkach za ubezpieczenie, które przekraczają ustawowy limit 9\% dla suszy przysługuje, zgodnie a art. 5 ust. 7 a ustawy o ubezpieczeniach upraw, dopłata maksymalna (do stawki 9\%) ${ }^{25}$. Zgodnie z ustawą o ubezpieczeniach upraw w przypadku ubezpieczenia skutków suszy możliwe jest zastosowanie franszyzy redukcyjnej w wysokości 20\%, 25\% lub 30\% sumy ubezpieczenia. Z uwagi na to, że wszystkie dostępne produkty na rynku oferowały franszyzę w wysokości 25\%, w kalkulacjach przyjęto takąjej wysokość.

Bazując na powyższych założeniach, można obliczyć wielkość szkody, przy której korzyści finansowe z zawarcia ubezpieczenia od skutków suszy równoważą koszty finansowe. Przyjmując, że redukcja plonu ubocznego jest wprost proporcjonalna do redukcji plonu głównego oraz że redukcja plonów nie powoduje redukcji kosztów bezpośrednich

$$
W F_{b u}=P-K
$$

gdzie

23. P. Gradziuk, Gospodarcze znaczenie i możliwości wykorzystania słomy na cele energetyczne w Polsce. Monografie i rozprawy naukowe nr 45, Wydawnictw IUNG-PIB w Puławach, Puławy 2015, s. 60 i nast., A. Harasim, Plony słomy wybranych zbóż w zależności od sposobu jej zbioru, „Polish Jurnal of Agronomy” 2016, nr 26, s. 38.

24. A. Harasim, Relacja między plonem słomy i ziarna u zbóż, „Pamiętnik Puławski” 1994, nr 104, za P. Gradziuk, op. cit., s. 72.

25. Zob. przypis 26 . 
$W F_{b u}$ - wynik finansowy bez zawarcia ubezpieczenia od suszy ( $w$ zł)

$P$ - całość przychodów z 1 ha uprawy (plon główny i plon uboczny) (w zł)

$K$ - całość kosztów na 1 ha uprawy bez składki ubezpieczeniowej (w zł)

oraz

gdzie

$$
W F_{u}=P+O-K-S
$$

$W F_{u}$ - wynik finansowy z ubezpieczeniem bez dotacji ( $w$ zł)

0 - odszkodowanie (w zł)

$S$ - składka za ubezpieczenie od skutków suszy bez dotacji (w zł)

Możemy stwierdzić, że

$$
\begin{aligned}
W F_{u} & =W F_{b z} \\
P+O-K & -S=P-K \\
0 & =S
\end{aligned}
$$

Z uwagi na to, że umowa ubezpieczenia jest zawsze odpłatna, równość ta może zajść wtedy i tylko wtedy, gdy $0>0$. Przy przyjętej w ustawie 25-procentowej wysokości franszyzy integralnej równość ta może zajść zatem tylko przy szkodzie $\geq 25 \%$ plonu.

Jeżeli

gdzie

$$
0=p \times q \times\left[s z-f_{r}\right]
$$

$s z$ - szkoda (w \%); sz $\geq 25$

$p$ - cena za $1 \mathrm{dt}$ ( $w$ zł)

$q$ - plon z 1 ha $(\mathrm{dt})$

$f_{r}$ - poziom franszyzy redukcyjnej $(\mathrm{w} \%)$, gdzie $f_{r} \in\{20 ; 25 ; 30\}$

oraz

$$
S=s \times q \times q
$$

gdzie

s - stopa składki ubezpieczeniowej za ubezpieczenie od skutków suszy stosowanej przez zakład ubezpieczeń (w \%)

równanie (5) jest spełnione, gdy

$$
s z=\frac{s}{p \times q}+f_{r}
$$

co jest równoważne

$$
S Z=s+f_{r}
$$

W przypadku dotowanego ubezpieczenia obejmującego skutki suszy, gdy $s \leq 9 \%$ dla upraw prowadzonych na użytkach rolnych klasy I-IV lub $s \leq 12 \%$ dla upraw prowadzonych na użytkach rolnych klasy V lub $s \leq 15 \%$ dla upraw prowadzonych na użytkach rolnych klasy VI równanie (6) przyjmuje postać ${ }^{26}$

gdzie

$$
s z=\frac{s_{d}}{p \times q}+f_{r}=\frac{s}{p \times q} \times 0,35+f_{r}
$$

26. Przy założeniu, że dopłaty do składek wynoszą 65\% (dopłaty w tej wysokości stosowane są od 2016 r.). 
$S_{d}$ - składka za ubezpieczenie od skutków suszy po dotacji płacona przez rolnika (w zł) natomiast równanie (?)

$$
s z=s_{d}+f_{r}=s \times 0,35+f_{r}
$$

$s_{d}$ - stopa składki za ubezpieczenie od skutków suszy po dotacji ( $\mathrm{w} \%$ )

W sytuacji, gdy s > 9\% (lub odpowiednio 12\% albo 15\%) i ubezpieczenie dotowane upraw obejmuje także inne - oprócz ubezpieczenia od skutków suszy i skutków złego przezimowania - zdarzenia, dotacja do składki jest obniżana proporcjonalnie do stopnia przekroczenia przez sumę stawek za ubezpieczone ryzyka (z wyłączeniem stawki za skutki suszy i złego przezimowania) stawek maksymalnych ${ }^{27}$. W sytuacji natomiast, gdy bierze się pod uwagę ubezpieczenie tylko od skutków suszy lub tylko od skutków złego przezimowania (lub tylko od skutków obu tych zdarzeń), których stawki (lub suma stawek) przekracza stawki maksymalne, wysokość dopłaty jest dyskusyjna ${ }^{28}$.

W poniższych tabelach przedstawiono wynik finansowy uzyskiwany z 1 ha uprawy, wartość wskaźnika pokrycia kosztów bezpośrednich $\left(W_{p k b}\right)$ oraz wartość wskaźnika zdolności odtworzenia majątku gospodarstwa (ZOM) w przypadku różnej wielkości szkód spowodowanych niedoborem wody. Tab. 5 prezentuje wyniki w odniesieniu do uprawy pszenicy, tab. 6 - rzepaku, tab. $?$ natomiast - kukurydzy na ziarno. Przedstawiono rezultaty wyliczeń dla szkód rosnących skokowo o 5 punktów procentowych, choć na potrzeby analizy dokonano obliczeń bardziej szczegółowych (które - z racji ograniczeń miejsca - nie zostały zamieszczone w publikacji, a przytoczono poniżej w tekście jedynie niektóre wyniki].

Komentując przedstawione rezultaty należy najpierw zauważyć, że w przypadku braku ubezpieczenia od skutków suszy analizowane uprawy przy różnym poziomie szkód suszowych zaczynają wykazywać ujemny wynik finansowy - pszenica już przy 19-procentowej szkodzie, kukurydza 21-procentowej, natomiast rzepak - dopiero przy 36-procentowej szkodzie. Jest to naturalnie związane z różną wysokością bezwzględną wyników finansowych wyjściowych (w sytuacji, gdy nie występuje szkoda).

27. Z wyłączeniem upraw drzew i krzewów owocowych oraz truskawek, dla których dotacja jest wypłacana do wysokości stawki maksymalnej.

28. Art. 5 ust. 7a ustawy o ubezpieczeniach upraw stanowi, że jeżeli określone przez zakłady ubezpieczeń stawki taryfowe ubezpieczenia z tytułu ubezpieczenia upraw, o których mowa wart. 3 ust. 1 pkt 1, z wyłączeniem upraw drzew i krzewów owocowych oraz truskawek, przekroczą stawki taryfowe ubezpieczenia określone w ust. 2 pkt 1, dopłaty przysługują w wysokości stanowiącej iloraz 1) iloczynu wysokości dopłat określonej w przepisach wydanych na podstawie ust. 10 i odpowiednio liczby 9, 12 lub 15 oraz 2) sumy ustalonych przez zakład ubezpieczeń stawek taryfowych ubezpieczenia od rodzajów ryzyka objętych ubezpieczeniem, o których mowa w art. 3 ust. 1 pkt 1, z wyłączeniem ryzyka suszy i ujemnych skutków przezimowania - nie większej jednak niż określona w ust. 2 pkt 1. Oznacza to, że w przypadku, gdy mamy do czynienia z ubezpieczeniem tylko od skutków suszy lub skutków złego przezimowania (lub obu tych zdarzeń), mianownik wskazanego ilorazu jest równy 0, co oznacza, że ilorazu tego nie można obliczyć(!). W przedstawionych w artykule kalkulacjach stawka maksymalna jest przekroczona w przypadku kukurydzy na ziarno (tab. ?]. W odniesieniu do tej uprawy przyjęto założenie, że dopłata wyniosłaby $65 \%$ stawki maksymalnej (9\%). Korzystniejszą interpretacją byłaby ta, że dopłata wynosi $65 \%$ stawki rzeczywistej. 
Tablica 5. Wynik finansowy na uprawie 1 ha pszenicy w przypadku szkód spowodowanych suszą

\begin{tabular}{|c|c|c|c|c|c|c|c|c|c|c|c|c|c|}
\hline $\begin{array}{l}\text { Wysokość } \\
\text { szkody (w \%) }\end{array}$ & 0 & 5 & 10 & 15 & 20 & 25 & 30 & 35 & 40 & 45 & 50 & 55 & 60 \\
\hline $\begin{array}{l}\text { Strata ubezpie- } \\
\text { czeniowa (przy- } \\
\text { chodów) w zł }\end{array}$ & 0,0 & 204,2 & 408,4 & 612,5 & 816,7 & 1020,9 & 1225,1 & 1429,3 & 1633,4 & 1837,6 & 2041,8 & 2246,0 & 2450,2 \\
\hline $\begin{array}{l}\text { Franszyza inte- } \\
\text { gralna } 25 \% \text { w zł }\end{array}$ & 1020,9 & 1020,9 & 1020,9 & 1020,9 & 1020,9 & 1020,9 & 1020,9 & 1020,9 & 1020,9 & 1020,9 & 1020,9 & 1020,9 & 1020,9 \\
\hline $\begin{array}{l}\text { Franszyza reduk- } \\
\text { cyjna } 25 \% \text { w zł }\end{array}$ & 0,0 & 0,0 & 0,0 & 0,0 & 0,0 & 1020,9 & 1020,9 & 1020,9 & 1020,9 & 1020,9 & 1020,9 & 1020,9 & 1020,9 \\
\hline \begin{tabular}{|l|} 
Wypłacone od- \\
szkodowanie w zł
\end{tabular} & 0,0 & 0,0 & 0,0 & 0,0 & 0,0 & 0,0 & 204,2 & 408,4 & 612,5 & 816,7 & 1020,9 & 1225,1 & 1429,3 \\
\hline $\begin{array}{l}\text { Wynik finansowy } \\
\text { na } 1 \text { ha bez ubez- } \\
\text { pieczenia upraw } \\
\text { od skutków su- } \\
\text { szy w zł }\end{array}$ & 907,4 & 669,9 & 432,4 & 194,8 & $-42,7$ & $-280,2$ & $-517,8$ & $-755,3$ & $-992,8$ & $-1230,4$ & $-1467,9$ & $-1705,4$ & $-1943,0$ \\
\hline \begin{tabular}{|l|} 
Wynik finan- \\
sowy na 1 ha \\
z uwzględnieniem \\
składki za ubez- \\
pieczenia upraw \\
od suszy bez \\
dotacji w zł \\
\end{tabular} & 662,4 & 424,9 & 187,4 & $-50,2$ & $-287,7$ & $-525,2$ & $-558,6$ & $\mid-592,0$ & $-625,3$ & $-658,7$ & $-692,0$ & $-725,4$ & $-758,7$ \\
\hline $\begin{array}{l}\text { Wynik finan- } \\
\text { sowy na } 1 \text { ha } \\
\text { z uwzględnieniem } \\
\text { składki za ubez- } \\
\text { pieczenie upraw } \\
\text { od suszy z dota- } \\
\text { cją w zł }\end{array}$ & 821,7 & 584,2 & 346,6 & 109,1 & $-128,5$ & $-366,0$ & $-399,3$ & $-432,7$ & $-466,1$ & $-499,4$ & $-532,8$ & $-566,1$ & $-599,5$ \\
\hline $\begin{array}{l}\text { Wpkb (przy } \\
\text { składce bez dota- } \\
\text { cji) }(\mathrm{w} \%)\end{array}$ & 0,0 & 0,0 & 0,0 & 0,0 & 0,0 & 0,0 & 5,9 & 11,7 & 17,6 & 23,4 & 29,3 & 35,2 & 41,0 \\
\hline $\begin{array}{l}\text { Wpkb (przy } \\
\text { składce dotowa- } \\
\text { nej) (w \%) }\end{array}$ & 0,0 & 0,0 & 0,0 & 0,0 & 0,0 & 0,0 & 6,1 & 12,3 & 18,4 & 24,6 & 30,7 & 36,8 & 43,0 \\
\hline $\begin{array}{l}\text { ZOM bez ubez- } \\
\text { pieczenia upraw } \\
\text { od skutków suszy } \\
\text { (w \%) }\end{array}$ & 220,0 & 188,6 & 157,2 & 125,8 & 94,4 & 62,9 & 31,5 & 0,1 & $-31,3$ & $-62,8$ & $-94,2$ & $-125,6$ & $-157,0$ \\
\hline $\begin{array}{l}\text { ZOM z ubezpie- } \\
\text { czeniem upraw } \\
\text { od skutków su- } \\
\text { szy [składka bez } \\
\text { dotacji] [w } \% \text { ] }\end{array}$ & 187,6 & 156,2 & 124,8 & 93,4 & 61,9 & 30,5 & 26,1 & 21,7 & 17,3 & 12,9 & 8,5 & 4,0 & $-0,4$ \\
\hline \begin{tabular}{l|} 
ZOM z ubezpie- \\
czeniem upraw \\
od skutków suszy \\
[składka z dota- \\
cja] $[$ w\% $]$ \\
\end{tabular} & 208,7 & 177,3 & 145,9 & 114,4 & 83,0 & 51,6 & 47,2 & 42,8 & 38,3 & 33,9 & 29,5 & 25,1 & 20,7 \\
\hline
\end{tabular}

Źródło: obliczenia własne.

W przypadku posiadania ubezpieczenia od skutków suszy i przy dotowanej składce ujemny wynik finansowy pojawia się dla pszenicy przy tych samych wielkościach szkód, co bez ubezpieczenia. Zgodnie z wzorem (9) w odniesieniu do szkód do 27\% plonu koszty finansowe posiadania ubezpieczenia od skutków suszy przeważają nad korzyściami (strata się pogłębia). Największa różnica występuje przy szkodzie w wysokości 19\% plonu, przy której bez ubezpieczenia osiagnięty zostałby minimalny dodatni wynik finansowy (4,8 zł/ha), natomiast przy posiadaniu ubezpieczenia wynik ujemny - 80,9 zł/ha, co oznaczałoby ponad 20-krotnie większą stratę. Im szkoda jednak jest wyższa, tym relacja wyniku z ubezpieczeniem do wyniku bez ubezpieczenia jest korzystniejsza. 
Przy szkodzie w wysokości ok. 27\% wyniki te są sobie równe. W odniesieniu do szkód o charakterze katastroficznym (co najmniej 30\%) ubezpieczenie wyraźnie łagodzi straty - strata przy posiadaniu ubezpieczenia od suszy jest niższa w przypadku szkody 30\% (60\%) o odpowiednio 23\% (70\%) aniżeli w sytuacji braku ubezpieczenia.

Tablica 6. Wynik finansowy na uprawie 1 ha rzepaku w przypadku szkód spowodowanych suszą

\begin{tabular}{|c|c|c|c|c|c|c|c|c|c|c|c|c|c|}
\hline $\begin{array}{l}\text { Wysokość } \\
\text { szkody (w \%) }\end{array}$ & 0 & 5 & 10 & 15 & 20 & 25 & 30 & 35 & 40 & 45 & 50 & 55 & 60 \\
\hline $\begin{array}{l}\text { Strata ubezpie- } \\
\text { czeniowa (przy- } \\
\text { chodów) w zł }\end{array}$ & 0,0 & 282,7 & 565,4 & 848,1 & 1130,9 & 1413,6 & 1696,3 & 1979,0 & 2261,7 & 2544,4 & 2827,1 & 3109,8 & 3392,6 \\
\hline $\begin{array}{l}\text { Franszyza inte- } \\
\text { gralna } 25 \% \text { w zł }\end{array}$ & 1413,6 & 1413,6 & 1413,6 & 1413,6 & 1413,6 & 1413,6 & 1413,6 & 1413,6 & 1413,6 & 1413,6 & 1413,6 & 1413,6 & 1413,6 \\
\hline $\begin{array}{l}\text { Franszyza re- } \\
\text { dukcyjna } 25 \% \\
\text { w zł }\end{array}$ & 0,0 & 0,0 & 0,0 & 0,0 & 0,0 & 1413,6 & 1413,6 & 1413,6 & 1413,6 & 1413,6 & 1413,6 & 1413,6 & 1413,6 \\
\hline $\begin{array}{l}\text { Wypłacone od- } \\
\text { szkodowanie } \\
\text { w zł }\end{array}$ & 0,0 & 0,0 & 0,0 & 0,0 & 0,0 & 0,0 & 282,7 & 565,4 & 848,1 & 1130,9 & 1413,6 & 1696,3 & 1979,0 \\
\hline $\begin{array}{l}\text { Wynik finanso- } \\
\text { wy na } 1 \text { ha bez } \\
\text { ubezpieczenia } \\
\text { upraw od skut- } \\
\text { ków suszy w zł }\end{array}$ & 2126,3 & 1823,8 & 1521,3 & 1218,8 & 916,3 & 613,8 & 311,3 & 8,8 & $-293,7$ & $-596,2$ & $-898,7$ & $-1201,2$ & $-1503,7$ \\
\hline $\begin{array}{l}\text { Wynik finan- } \\
\text { sowy na } 1 \text { ha } \\
\text { z uwzględnie- } \\
\text { niem składki } \\
\text { za ubezpieczenia } \\
\text { upraw od suszy } \\
\text { bez dotacji w zł }\end{array}$ & 1854,9 & 1552,4 & 1249,9 & 947,4 & 644,9 & 342,4 & 322,6 & 302,8 & 283,0 & 263,2 & 243,4 & 223,6 & 203,8 \\
\hline $\begin{array}{l}\text { Wynik finan- } \\
\text { sowy na } 1 \text { ha } \\
\text { z uwzględnie- } \\
\text { niem składki } \\
\text { za ubezpieczenie } \\
\text { upraw od suszy } \\
\text { z dotacją w zł }\end{array}$ & 2031,3 & 1728,8 & 1426,3 & 1123,8 & 821,3 & 518,8 & 499,0 & 479,2 & 459,4 & 439,6 & 419,8 & 400,0 & 380,3 \\
\hline $\begin{array}{l}\text { Wpkb (przy } \\
\text { składce bez do- } \\
\text { tacji) (w \%) }\end{array}$ & 0,0 & 0,0 & 0,0 & 0,0 & 0,0 & 0,0 & 7,9 & $15, ?$ & 23,6 & 31,5 & 39,3 & 47,2 & 55,0 \\
\hline $\begin{array}{l}\text { Wpkb (przy } \\
\text { składce doto- } \\
\text { wanej] }\end{array}$ & 0,0 & 0,0 & 0,0 & 0,0 & 0,0 & 0,0 & 8,3 & 16,5 & 24,8 & 33,1 & 41,3 & 49,6 & 57,9 \\
\hline $\begin{array}{l}\text { ZOM bez ubez- } \\
\text { pieczenia upraw } \\
\text { od skutków su- } \\
\text { szy [w \%] }\end{array}$ & 410,7 & 366,5 & 322,3 & 278,1 & 233,9 & 189,7 & 145,5 & 101,3 & 57,1 & 12,9 & $-31,3$ & $-75,5$ & $-119,7$ \\
\hline $\begin{array}{l}\text { ZOM z ubezpie- } \\
\text { czeniem upraw } \\
\text { od skutków su- } \\
\text { szy [składka bez } \\
\text { dotacji) (w \%) }\end{array}$ & 371,0 & 326,8 & 282,6 & 238,4 & 194,2 & 150,0 & 147,1 & 144,2 & 141,3 & 138,5 & 135,6 & 132,7 & 129,8 \\
\hline $\begin{array}{l}\text { ZOM z ubezpie- } \\
\text { czeniem upraw } \\
\text { od skutków } \\
\text { suszy [składka } \\
\text { z dotacja) (w \%) } \\
\end{array}$ & 396,8 & 352,6 & 308,4 & 264,2 & 220,0 & 175,8 & 172,9 & 170,0 & 167,1 & 164,2 & 161,3 & 158,4 & 155,6 \\
\hline
\end{tabular}

Źródło: obliczenia własne. 
Dla uprawy rzepaku (tab. 6) sytuacja wygląda inaczej. Ubezpieczenie od skutków suszy pozwala bowiem na osiaggnięcie dodatniego wyniku finansowego nawet przy szkodzie w wysokości 60\% założonego plonu. Zgodnie z wzorem (9) dla szkód do 27\% wynik finansowy na 1 ha uprawy z ubezpieczeniem z dotacjajest niższy od wyniku finansowego uzyskiwanego bez ubezpieczenia. Następnie oba wyniki wyrównują się, po czym - jak wskazują kalkulacje zamieszczone w tab. 6 - są wyraźnie wyższe w przypadku posiadania ubezpieczenia aniżeli w przypadku jego braku.

Tablica ?. Wynik finansowy na uprawie 1 ha kukurydzy na ziarno w przypadku szkód spowodowanych suszą

\begin{tabular}{|c|c|c|c|c|c|c|c|c|c|c|c|c|c|}
\hline $\begin{array}{l}\text { Wysokość } \\
\text { szkody [w \%] }\end{array}$ & 0 & 5 & 10 & 15 & 20 & 25 & 30 & 35 & 40 & 45 & 50 & 55 & 60 \\
\hline $\begin{array}{l}\text { Strata ubezpie- } \\
\text { czeniowa (przy- } \\
\text { chodów) w zł }\end{array}$ & 0,0 & 296,0 & 592,0 & 888,0 & 1184,0 & 1480,0 & 1776,0 & 2072,0 & 2368,0 & 2664,0 & 2960,0 & 3256,0 & 3552,0 \\
\hline $\begin{array}{l}\text { Franszyza inte- } \\
\text { gralna } 25 \% \text { w zł }\end{array}$ & 1480,0 & 1480,0 & 1480,0 & 1480,0 & 1480,0 & 1480,0 & 1480,0 & 1480,0 & 1480,0 & 1480,0 & 1480,0 & 1480,0 & 1480,0 \\
\hline $\begin{array}{l}\text { Franszyza reduk- } \\
\text { cyjna } 25 \% \text { w zł }\end{array}$ & 0,0 & 0,0 & 0,0 & 0,0 & 0,0 & 1480,0 & 1480,0 & 1480,0 & 1480,0 & 1480,0 & 1480,0 & 1480,0 & 1480,0 \\
\hline $\begin{array}{l}\text { Wypłacone od- } \\
\text { szkodowanie w zł }\end{array}$ & 0,0 & 0,0 & 0,0 & 0,0 & 0,0 & 0,0 & 296,0 & 592,0 & 888,0 & 1184,0 & 1480,0 & 1776,0 & 2072,0 \\
\hline $\begin{array}{l}\text { Wynik finansowy } \\
\text { na } 1 \text { ha bez ubez- } \\
\text { pieczenia upraw } \\
\text { od skutków su- } \\
\text { szy w zł }\end{array}$ & 1285,2 & 968,5 & 651,7 & 335,0 & 18,3 & $-298,4$ & $-615,1$ & $-931,9$ & $-1248,6$ & $-1565,3$ & $\mid-1882,0$ & $-2198,7$ & $-2515,5$ \\
\hline $\begin{array}{l}\text { Wynik finan- } \\
\text { sowy na } 1 \text { ha } \\
\text { z uwzględnie- } \\
\text { niem składki } \\
\text { za ubezpieczenia } \\
\text { upraw od suszy } \\
\text { bez dotacji w zł } \\
\end{array}$ & $-11,3$ & $-328,0$ & $-644,7$ & $-961,5$ & $-1278,2$ & $-1594,9$ & $-1615,6$ & $-1636,3$ & $-1657,1$ & $-1677,8$ & $\mid-1698,5$ & $-1719,2$ & $-1739,9$ \\
\hline $\begin{array}{l}\text { Wynik finan- } \\
\text { sowy na } 1 \text { ha } \\
\text { z uwzględnie- } \\
\text { niem składki } \\
\text { za ubezpieczenie } \\
\text { upraw od suszy } \\
\text { z dotacją w zł } \\
\end{array}$ & 335,0 & 18,3 & $-298,4$ & $-615,1$ & $-931,9$ & $-1248,6$ & $-1269,3$ & $-1290,0$ & $-1310, ?$ & $-1331,5$ & $\mid-1352,2$ & $-1372,9$ & $-1393,6$ \\
\hline $\begin{array}{l}W_{\text {pkb }} \text { (przy skład- } \\
\text { ce bez dotacji) } \\
{[\mathrm{w} \%]}\end{array}$ & 0,0 & 0,0 & 0,0 & 0,0 & 0,0 & 0,0 & 5,1 & 10,2 & 15,4 & 20,5 & 25,6 & 30,7 & 35,8 \\
\hline $\begin{array}{l}\mathrm{W}_{\mathrm{pkb}} \text { (przy skład- } \\
\text { ce dotowanej] } \\
{[\mathrm{w} \%]}\end{array}$ & 0,0 & 0,0 & 0,0 & 0,0 & 0,0 & 0,0 & 5,4 & 10,9 & 16,3 & 21,8 & 27,2 & 32,7 & 38,1 \\
\hline $\begin{array}{l}\text { ZOM bez ubez- } \\
\text { pieczenia upraw } \\
\text { od skutków su- } \\
\text { szy [w \%] }\end{array}$ & 292,2 & 244,8 & 197,5 & 150,1 & 102,7 & 55,4 & 8,0 & $-39,3$ & $-86,7$ & $-134,1$ & $-181,4$ & $-228,8$ & $-276,2$ \\
\hline $\begin{array}{l}\text { ZOM z ubezpie- } \\
\text { czeniem upraw } \\
\text { od skutków su- } \\
\text { szy [składka bez } \\
\text { dotacji] [w \% ] }\end{array}$ & 98,3 & 50,9 & 3,6 & $-43,8$ & $-91,1$ & $-138,5$ & $-141,6$ & $-144, ?$ & $-147,8$ & $-150,9$ & $|-154,0|$ & $-157,1$ & $-160,2$ \\
\hline $\begin{array}{l}\text { ZOM z ubezpie- } \\
\text { czeniem upraw } \\
\text { od skutków su- } \\
\text { szy [składka } \\
\text { z dotacją) [w\%] } \\
\end{array}$ & 150,1 & 102,7 & 55,4 & 8,0 & $-39,3$ & $-86,7$ & $-89,8$ & $-92,9$ & $-96,0$ & $-99,1$ & $-102,2$ & $-105,3$ & $-108,4$ \\
\hline
\end{tabular}

Źródło: obliczenia własne. 
Dla kukurydzy (tab. ?), z uwagi na bardzo wysoki koszt składki ubezpieczeniowej, wynik finansowy w przypadku zawarcia ubezpieczenia od suszy (z dotacja) jest ujemny już przy szkodzie w wysokości 6\% założonego plonu. Wynik finansowy przy ubezpieczeniu z dotacja jest wyższy (strata jest mniejsza) w porównaniu do wyniku finansowego bez ubezpieczenia dopiero przy szkodzie wyższej aniżeli 41\% (por. wzór (9) i przypis 28).

Można zatem wnioskować, że zawarcie umowy ubezpieczenia od suszy zawsze obniża wynik finansowy dla szkód poniżej franszyzy integralnej (25\% założonego plonu), po czym prowadzi do poprawy tego wyniku, choć nie zawsze tak silnie, aby był dodatni. Wielkość szkody, przy której ubezpieczenie skutkuje podwyższeniem wyniku (lub zmniejszeniem straty), jest różna dla różnych upraw - dla pszenicy i rzepaku wynosi ok. 27\%, natomiast dla kukurydzy dopiero 41\%. W przypadku ubezpieczenia komercyjnego (bez dopłaty) zgodnie ze wzorem (?) pozytywny wpływ ubezpieczenia od suszy występuje od szkody 31\% dla pszenicy, 30\% dla rzepaku oraz 47\% dla kukurydzy. Dopłaty do składki obniżają zatem o ok. 15\% wielkość szkody, przy której producent rolny odczuje pozytywny finansowy wpływ ubezpieczenia dla pszenicy i kukurydzy, natomiast o ok. $12 \%$ - dla rzepaku.

Te zależności przekładaja się na wartości wskaźnika ZOM. Zdolność do reprodukcji prostej majątku jest utracona w momencie uzyskania negatywnego wyniku finansowego. Oznacza to, że w przypadku braku ubezpieczenia od suszy dla uprawy pszenicy nie ma jej już przy szkodzie 19\% i później tylko maleje. Tempo utraty tej zdolności może być wyraźnie zahamowane przez posiadanie ubezpieczenia od skutków suszy w przypadku szkód w pszenicy powyżej 27\% plonu. Odszkodowanie nie jest w stanie jednak przywrócić zdolności do prostego odtworzenia majątku. Z kolei ZOM w odniesieniu do rzepaku już wyjściowo, tj. przy braku jakichkolwiek szkód i bez ubezpieczenia, jest niemalże dwukrotnie wyższy aniżeli przy pszenicy, spada natomiast poniżej $100 \%$ i powoduje reprodukcję zawężoną przy szkodzie 36\% założonego plonu lub wyższej. Ubezpieczenie dla szkód w rzepaku od 27\% zawsze wyhamowuje utratę możliwości odtworzenia majątku i to w takim stopniu, że pozwala na jego rozszerzoną reprodukcję nawet przy szkodach 60\%. Dla kukurydzy reprodukcja prosta bez ubezpieczenia jest utracona przy $21 \%$ stracie plonu, natomiast ubezpieczenie ogranicza spadek ZOM dopiero dla szkód powyżej 40\%. Dla szkód do 25\% koszty zawarcia ubezpieczenia od skutków suszy obniżają ZOM ${ }^{29}$ o 11 punktów procentowych (pszenica), 14 punktów procentowych (rzepak) oraz 142 punkty procentowe (kukurydza).

Jak wspomniano wyżej, odszkodowanie należne jest dopiero dla szkód w wysokości co najmniej 25\% plonu, co oznacza, że ewentualne pokrycie kosztów poniesionych na uprawę przez odszkodowanie można rozważać tylko wtedy, gdy nastapiła utrata co najmniej jednej czwartej plonu. W przypadku pszenicy pokrycie kosztów bezpośrednich wynosi od 6\% (szkoda 30\%) do 43\% (szkoda $60 \%$ ], rzepaku od $8 \%$ (szkoda 25\%) do 58\% (szkoda 60\%), kukurydzy od 5\% (szkoda 30\%) do 38\% (szkoda 60\%). Jak widać, otrzymywane odszkodowanie przy franszyzie 25\% nie pokrywa bezpośrednich kosztów produkcji. Przy franszyzie najmniejszej z dopuszczonych, tj. wynoszącej 20\%, stopień pokrycia kosztów bezpośrednich wyniósłby dla pszenicy od 6,1\% (szkoda 25\%) do 49,1\% (szkoda 60\%), rzepaku od 8,3\% (szkoda 25\%) do 66,1\% (szkoda 60\%), od 5,4\% (szkoda 25\%) do $43,5 \%$ (szkoda 60\%) dla kukurydzy (i to przy utrzymaniu tej samej stawki, co dla ubezpieczenia

29. Zawarcie ubezpieczenia od skutków suszy obniża ZOM (zdolność do odtworzenia majątku) dla szkód do 25\%, co jest oczywiste, ponieważ wówczas nie należy się odszkodowanie, a koszty związane z zakupem ubezpieczenia zostały poniesione. 
z 25\% franszyza). Przy tych warunkach rynkowych założenie ustawodawcy, jakoby odszkodowanie miało pozwolić na pokrycie kosztów bezpośrednich produkcji, uznać należy za nierealne.

Biorąc pod uwagę trzy elementy - wynik finansowy uzyskany z 1 ha uprawy, wskaźnik ZOM oraz pokrycie przez odszkodowanie kosztów bezpośrednich uprawy - można stwierdzić, że przy przyjętych w kalkulacjach stawkach za ubezpieczenie od suszy, warunkach ochrony ubezpieczeniowej oraz warunkach rynkowych (cenach za produkty rolne i kosztach ich produkcji) jednolite zasady ubezpieczenia dotowanego od skutków suszy w odniesieniu do różnych upraw prowadzą do bardzo zróżnicowanego poziomu wsparcia finansowego producentów rolnych w przypadku wystapienia szkód.

\section{Podsumowanie}

Wdrożenie ubezpieczeń dotowanych upraw w 2005 roku opierało się na kilku celach zdefiniowanych w uzasadnieniu do ustawy ${ }^{30}$ :

- zmniejszeniu obciążenia budżetu państwa w kontekście pokrywania skutków niekorzystnych zjawisk atmosferycznych w produkcji roślinnej,

- upowszechnieniu dostępności do środków na wznowienie produkcji rolniczej w przypadku poniesienia strat wskutek zdarzeń klęskowych dla podstawowych kierunków produkcji,

- ograniczeniu ryzyka utraty przychodów,

- umożliwieniu podniesienia konkurencyjności polskich gospodarstw rolnych,

- wpływie na sytuację i rozwój regionów.

Stosowanie przez prawie 15 lat ubezpieczeń dotowanych upraw doprowadziło do zwiększenia wykorzystania przez producentów rolnych tego rodzaju narzędzia zarządzania ryzykiem w pokrywaniu zaistniałych strat. Wyniki badania wskazują, że zakres i efektywność tego wykorzystania jest zmienny w zależności od rodzajów zdarzeń. Zarówno świadczenia wypłacane z tytułu skutków złego przezimowania, jak i skutków suszy tylko w części pokrywają konsekwencje finansowe tych zdarzeń dla producenta rolnego.

W odniesieniu do ubezpieczenia skutków złego przezimowania należy podkreślić, iż pomimo stosowanych techniczno-ubezpieczeniowych ograniczeń odpowiedzialności, korzystanie z ubezpieczeń zapewnia stabilizację funkcjonowania, co zostało określone poprzez kalkulację wskaźnika zdolności odtworzenia majątku gospodarstwa (ZOM).

W przypadku ubezpieczenia od skutków suszy z równania (9) wyraźnie widać, że przy przyjęciu założenia o proporcjonalnej redukcji plonu ubocznego oraz braku redukcji kosztów bezpośrednich, poziom szkody, od której zaczyna „opłacać się” ubezpieczenie od suszy, zależy bezpośrednio od stopy składki i poziomu franszyzy redukcyjnej (i zawsze będzie on wyższy niż $25 \%$ wskutek przyjętej w ustawie wysokości franszyzy integralnej]. Nie zależy on zatem od kosztów zainicjowania uprawy czy przyjętej sumy ubezpieczenia. Te wielkości i ich zmienność, przekładająca się na zmienność wyników finansowych, nie wpływają na poziom szkody, od której finansowe korzyści z ubezpieczenia przeważają nad kosztami. Konstatacja ta może pomóc w podejmowaniu decyzji o zawarciu ewentualnego ubezpieczenia producentom rolnym.

30. Uzasadnienie do ustawy z dnia 7 lipca 2005 r. o dopłatach do ubezpieczeń upraw rolnych i zwierząt gospodarskich (Dz. U. 2005, nr 150, poz. 1249). 
Stawka za ubezpieczenie od skutków suszy jest regulowana rynkowo, a wysokość franszyzy redukcyjnej - z trzech możliwych dopuszczonych przez ustawę o ubezpieczeniach upraw - dotychczas narzucana przez zakłady ubezpieczeń. Oznacza to, że na „opłacalność” ubezpieczeń ma wpływ sytuacja na rynku ubezpieczeniowym, a nie sytuacja na rynkach rolnych. Ingerencja państwa w zakresie upowszechniania ubezpieczenia upraw słusznie zatem jest skierowana na elementy ubezpieczeniowe - poziom dotacji składki lub inne elementy mające wpływ na wysokość stawki (reasekuracja, poziomy franszyz, karencja ubezpieczeniowa).

Wysokość stawki za ubezpieczenie oraz wysokość franszyzy redukcyjnej są od siebie zależne. Co do zasady, im większy poziom franszyzy redukcyjnej, tym niższa stopa składki. Zmiany te jednak nie muszą być proporcjonalne. W odniesieniu do ubezpieczenia od skutków suszy dla wielkości szkody „granicznej”, tj. takiej, od której korzyści finansowe dla producenta rolnego przeważają nad kosztami, istotne jest łączne rozważanie stawki i franszyzy. W przypadku różnicowania stawek dla tej samej uprawy, a także przy różnych stawkach dla różnych upraw, pozytywny efekt finansowy występuje przy różnych wielkościach szkód. Przekłada się to bezpośrednio na zdolność do odtworzenia majątku trwałego. Trudno zatem mówić o tym samym poziomie ochrony dla producentów rolnych prowadzących uprawy tych samych oraz różnych gatunków. Pozostaje postawić pytanie, czy państwo - jako główny organizator systemu upraw dotowanych - efekt taki przewidziało i czy był on zamierzony. Dla pełności obrazu dodać należy, że ubezpieczenie upraw od suszy nie pozwala także - wbrew założeniom ustawodawcy - na pokrycie kosztów bezpośrednich założenia i realizacji uprawy w okresie wegetacji.

Ubezpieczenie upraw od suszy jest jednym z elementów kontroli ryzyka w gospodarstwie rolnym. Stąd poziom, od którego pozytywnie oddziałuje ono na wynik finansowy gospodarstwa, stanowi o „atrakcyjności” tego instrumentu względem innych dostępnych rozwiązań prewencyjnych oraz decyduje o tym, w restytucji jakiej wielkości szkód realnie jest w stanie pomóc. Z uwagi na istnienie franszyzy integralnej i redukcyjnej w wysokości $25 \%$ oraz wskazanej wielkości szkód "granicznych" można stwierdzić, że ubezpieczenie dotowane od skutków suszy dedykowane jest dla szkód, które w widoczny sposób wpływaja na pogorszenie sytuacji gospodarstwa rolnego i poziomu życia rodziny ${ }^{31}$. Im szkoda w wyższym stopniu ma charakter katastroficzny, tym ubezpieczenie w wyższym stopniu łagodzi jej skutki (różnica w korekcie in plus wyniku finansowego jest procentowo wyższa].

Powyższe wyliczenia dotyczące szkody „granicznej” w odniesieniu do suszy mogą w praktyce okazać się tylko szacunkowe w sytuacji, gdy likwidacja szkody powstałej jako skutek suszy byłaby dokonywana metodą szczegółową, a szacowany plon potencjalny nie pokrywałby się z plonem przyjętym przy zawieraniu umowy ubezpieczenia. Różnice mogłyby także powstać w przypadku, gdy szacowana przez zakład ubezpieczeń wielkość tzw. nieponiesionych kosztów byłaby różna od zera.

Uwzględniając powyższe wnioski, należy podkreślić, że decyzja dotycząca ubezpieczenia od skutków suszy danej uprawy w danej lokalizacji musi uwzględniać całość dochodów gospodarstwa, zarówno z produkcji roślinnej, jak i zwierzęcej. Należy wzią́ pod uwagę nie tylko straty bezpośrednie skutków suszy, ale także straty pośrednie (na przykład w kontekście braku paszy

31. Są to szkody od 37,4\% plonów. Szkody powyżej 59,4\% plonów powoduja poważne konsekwencje finansowe, a nawet bankructwo gospodarstwa. Szerzej: Identyfikacja podstaw..., s. 592-593. 
dla bydła i konieczności redukcji liczby zwierząt lub spadku ich dobrostanu ${ }^{32}$. Konstatacja ta może stać się przyczynkiem do dalszych badań.

\section{Wykaz źródeł}

Druk nr 2909, Rzqdowy projekt ustawy o zmianie ustawy o ubezpieczeniach upraw rolnych i zwierzat gospodarskich - uzasadnienie, http://www.sejm.gov.pl/Sejm8.nsf/druk.xsp?nr=2909 [dostęp: 16.12.2020].

Gradziuk P., Gospodarcze znaczenie i możliwości wykorzystania słomy na cele energetyczne w Polsce, ,Monografie i rozprawy naukowe IUNG-PIB w Puławach” 2015, nr 45.

Grzelak A., Ocena procesów reprodukcji majatku gospodarstw rolnych prowadzacych rachunkowość rolnq (FADN), „Zagadnienia Ekonomiki Rolnej” 2014, nr 3.

Harasim A., Plony słomy wybranych zbóż w zależności od sposobu jej zbioru, „Polish Jurnal of Agronomy" 2016, nr 26.

http://www.wir.org.pl/kalk/kalk.htm [dostęp: 20.09.2020].

Identyfikacja podstaw, przemian i problemów ubezpieczeń rolnych, Soliwoda M. [red.], Instytut

Ekonomiki Rolnictwa i Gospodarki Żywnościowej - Państwowy Instytut Badawczy, Warszawa 2020.

Janowicz-Lomott M., Łyskawa K., Funkcjonowanie dotowanych ubezpieczeń upraw w Polsce, „Wiadomości Ubezpieczeniowe” 2016, nr 2.

Kaczała M., Systemowe ryzyko suszy rolniczej a ubezpieczenia. Zadania dla państwa, Wydawnictwo Uniwersytetu Ekonomicznego w Poznaniu, Poznań 2019.

Koza P., Łopatka A., Jadczyszyn J., Wawer R., Doroszewski A., Siebielec G., Ekspertyza „Wyznaczenie obszarów w różnym stopniu zagrożonych wystapieniem suszy w Polsce na potrzeby wdrażania operacji „Modernizacja gospodarstw rolnych” Programu Rozwoju Obszarów Wiejskich na lata 2014-2020", Puławy 2019, https://www.gov.pl/web/rolnictwo/publikacje [dostęp: 10.10.2020]. Łabędzki L., Potrzeby wodne roślin uprawnych i potrzeby nawodnień w zlewni rzeki Zgłowiqczki, „Wirtualny Instytut Rolnictwa Zrównoważonego” 2007, nr 4.

MRiRW, Ubezpieczenia z uwzględnieniem stabilizacji dochodów jako instrumenty zarzadzania ryzykiem w rolnictwie, Warszawa 29 września $2020 \mathrm{r}$.

NIK (2020), Wspieranie środkami publicznymi systemu ubezpieczeń rolniczych, https://www.nik. gov.pl/kontrole/P/19/047/ [dostęp: 10.09.2020].

Ogólne warunki obowiązkowego oraz dobrowolnego dotowanego ubezpieczenia upraw rolnych „Bezpieczne Uprawy ” zatwierdzone Uchwałą nr 132/2018 Zarządu Pocztowego Towarzystwa Ubezpieczeń Wzajemnych z dnia 12 września 2018 r.

Ogólne warunki ubezpieczenia PZU UPRAWY, ustalone uchwałą nr UZ/235/2019 Zarządu Powszechnego Zakładu Ubezpieczeń Spółki Akcyjnej z dnia 2 września 2019 r. ze zmianami ustalonymi uchwała Zarządu Powszechnego Zakładu Ubezpieczeń Spółki Akcyjnej nr UZ/207/2020 z dnia 14 lipca $2020 \mathrm{r}$.

Ogólne Warunki Ubezpieczenia UPRAW ROLNYCH Concordia Polska TU SA zatwierdzone Uchwała Zarządu Ubezpieczyciela i wchodzą w życie z dniem 1 stycznia 2020 r.

32. Szerzej zob. M. Kaczała, op. cit., s. 73 i nast. 
Ogólne warunki ubezpieczenia upraw rolnych Vereinigte Hagelversicherung VVaG zatwierdzone Uchwałą Zarządu Ubezpieczyciela nr 8/2019 z dnia 30 listopada 2019 r.

Ogólne warunki ubezpieczenia upraw rolnych zatwierdzone uchwałą nr 01/13/11/2019 Zarządu InterRisk Towarzystwo Ubezpieczeń Spółka Akcyjna Vienna Insurance Group z dnia 13 listopada 2019 r.

Orlicki M., Ubezpieczenia obowiqzkowe, Wolter Kluwer, Warszawa 2011.

Pabiszczak K., Wysocki G., Kalkulacje rolnicze, „Siewca Wielkopolski” 2001, nr 6.

PIU [2008], Kierunki zmian ubezpieczeń produkcji rolnej w Polsce. Materiały z konferencji zorganizowanej przez Polska Izbę Ubezpieczeń w Warszawie w dniu 4.02.2008 r.

\section{The effect of the subsidized crop insurance on the financial result of selected types of plant production}

The changing environment of farms, i.e. the increasing number and intensity of catastrophic phenomena and the obligation to limit direct aid provided by the state as part of ad hoc activities, has led to introduction of subsidized crop insurance in Poland. However, the scope of notoriously changing regulations in this area leads to questioning the efficiency of insurance protection offered to the most important entities: farms. The aim of the study is to determine the impact of using insurance cover in subsidized insurance on the financial result obtained from production of selected crops and with respect to events causing mass damage: winterkill and drought. Based on the methodology of calculating the financial result of a farm, an assessment of the impact of the insurance contracts on the farm assets replacement capacity index (ZOM) was carried out. The intention of subsidized crop insurance was to offer stability of functioning to farms affected by the impact of unfavourable weather phenomena. The conducted analysis clearly shows that the efficiency of insurance protection against winterkill depends both on the economic parameters of the farm's operation and the applicable regulations in the field of technical conditions of insurance contracts, while in the case of insurance against drought, on two parameters - the rate for insurance and the level of the deductible.

Key words: crop insurance, winterkill cover, drought, financial result, plant production.

MONIKA KACZAŁA - Katedra Ubezpieczeń, Instytut Finansów, Uniwersytet Ekonomiczny w Poznaniu. Monika.Kaczala@ue.poznan.pl

Orcid: 0000-0003-1868-7835

KRZYSZTOF ŁYSKAWA - Katedra Ubezpieczeń, Instytut Finansów, Uniwersytet Ekonomiczny w Poznaniu.

Krzysztof.Lyskawa@ue.poznan.pl

ORCID: 0000-0002-7409-8624 
